\title{
5 Do Chinese power companies employ investments in foreign power projects as a geographical diversification strategy?
}

\author{
Akihisa Mori
}

\section{Introduction}

Recent global and national stringent climate policy refuels the debate over its impacts on industrial competitiveness, industrial relocation, and the resultant carbon leakage and haven effects. Industry relocation, the move of industries from one region to another, occurs as a result of economic development, labor cost changes, regional policy discrepancies, and various other factors (Tobey, 1990; Penning and Sleuwaegen, 2000). Environmental and climate policies can be one of the drivers for industrial relocation, and the relocation of emissions. They trigger pollution and carbon havens. If the stringent environmental regulation adversely affects electricity cost and comparative advantage and this effect is sufficiently strong to dominate other sources of comparative advantage, it determines the pattern of trade in pollution and carbon-intensive industries (Cherniwchan et al., 2017; Panhans et al., 2017; Zhao et al., 2020).

Behind the refueling of the pollution haven debate are stringent environmental, energy, and climate policies that have been recently implemented in the European Union (EU), China, and worldwide. Stringent regulations and carbon pricing, as represented in carbon emissions trading schemes, raise concerns about industrial competitiveness and carbon leakage. Perceiving coal power as one of the main sources of global $\mathrm{CO}_{2}$ emissions, Organization for Economic Co-operation and Development (OECD) member countries have propped up commitments to common standards for coal subsidies and restrictions on international finance for coal power (OECD, 2015). To reaffirm China's firm commitment to the Paris Agreement, the Obama administration initiated a joint statement over China's restriction on public financing for projects with high pollution or carbon emissions in 2015 (White House, 2015).

By contrast, China has increased investments in and financing for foreign coal power projects. China started providing overseas official finance (OOF) in the resource extraction sector in the early 2000s and expanded the scope to infrastructure development, including investments in newly installed capacity (i.e., greenfield investment) in the electricity sector. To reduce country and commercial risks, the country employed the resource-financed 
infrastructure in which host country governments pledged their interest in some or all of the revenue flows they will receive from the resource production project to a lender (Beardsworth and Schmidt, 2014). In addition, the Chinese government established bilateral and regional development funds to finance investments in connectivity infrastructure as a part of the Belt and Road Initiative (BRI). These funds combined equal more than US\$164.4 billion, of which the Silk Road Fund accounted for the largest share (Gallagher et al., 2018). Subsequently, Chinese companies began brownfield investment, comprising the acquisition of shares of existing power companies and utilities and the generation, transmission, and distribution assets under construction and in operation. ${ }^{1}$

These funds not only provide opportunities for Chinese companies to invest in foreign connectivity infrastructure projects such as high-speed trains and information and communication technologies but also accelerate cross-border relocation of pollution and carbon-intensive industries and displacement of $\mathrm{CO}_{2}$ emissions in foreign countries with less stringent climate and environmental policies. These investments and financing will not only breach the joint statement but also replace OECD member countries' foreign coal power financing, more than offsetting global commitments to the Paris Agreement.

In addition, Chinese investments and financing in foreign power projects can reconfigure the electricity supply system in host countries toward a carbon-intensive version by making coal power profitable and increasing the number of coal power projects. Even if new coal power generation capacity helps host countries overcome power shortages and provide the electricity necessary for economic development and society in the short run, they can result in stranded assets in the long run, namely, assets that are no longer able to earn an economic return at some time before the end of their economic life (IEA, 2013: 98).

For these reasons, the EU does not hide its cautious stance against China's carbon-neutral pledge by 2060 in the UN Summit in 2020, despite evaluating it as an important step (Xie, 2020).

An increasing number of researchers have investigated China's investments in foreign coal power projects. The first strand of research relates to estimating the scale of China's finance for coal power development to identify drivers of the scaling and characteristics of finance. In 2005-2014, China's finance for coal power projects was estimated to be US\$21-38 billion, of which two-thirds were allocated to India, Indonesia, and Vietnam. The two policy banks-Export-Import Bank of China (CHEXIM) and the China Development Bank (CDB) financed US\$15 billion for foreign coal power projects (Hervé-Mignucci and Wang, 2015). In 2005-2017, the two policy banks financed US\$42 billion more than 59 coal plants (Gallagher et al., 2018).

Li et al. (2020) estimated that Chinese power companies invested approximately US $\$ 115$ billion in 462 foreign power plants in 2000-2017, with a total generation capacity of $81 \mathrm{GW}$. Among the $81 \mathrm{GW}$ of capacity, coal accounts 
for $31 \%$ or $25 \mathrm{GW}$. However, they excluded Chinese companies' involvement in power projects as contractors, which may underestimate the scale, especially that of new coal power generation capacity, thus potentially impacting $\mathrm{CO}_{2}$ emissions. Chinese incumbent generators often start out exploring foreign markets through smaller-scale engineering, procurement, and construction (EPC) contracts through subsidiaries, and after a few years of gaining experience and confidence in operating in the host country, they begin to invest in larger-scale projects (Hervé-Mignucci and Wang, 2015). When including EPC contracts, China is involved in a greater number of foreign coal power projects: 114 coal power projects in operation and 54 projects under construction in the BRI countries in 2001-2016, with a combined installed capacity of $88 \mathrm{GW}$ and $48 \mathrm{GW}$, respectively (Peng et al., 2017).

The second strand of research concerns environmental and climatic impacts. Chinese foreign coal plants are relatively less efficient than those financed by Japan's export credit agency (Ueno et al., 2014) because the majority of coal power plants deploy subcritical coal technology (Gallagher et al., 2018). This inefficient, pollution-intensive coal power increases the social cost of Chinese foreign power plants, which is US\$29.7 billion annually, even by conservative estimates (Gallagher, 2018a). By contrast, NDCs to the Paris Agreement encourage host countries to prop up environmental pressures on foreign coal power investments (Xiong et al., 2019). It is argued that an increasing number of coal power projects have been opposed by fierce local protests and raised political debates, causing substantial delays and cancellations (Boulle, 2019; Vidal, 2016). In response, China has reduced investments and finance for subcritical coal plants (Gallagher et al., 2018). Nonetheless, the total BRI-associated power projects in the 15 countries in 2013-2019 are estimated to generate 37 (range 26-48) gigatonnes (Gt) of committed $\mathrm{CO}_{2}$ emissions by the end of 2030 , which is $4 \%-11 \%$ of the remaining carbon budget for the $1.5^{\circ} \mathrm{C}$ target (Tao et al., 2020).

However, this strand of research has not yet explored the interaction between domestic environmental and climate policy and foreign direct investment (FDI) in power projects. It has tended to frame Chinese FDI in coal power projects as a response to the "going global strategy" and BRI and recognized domestic coal power overcapacity caused by declining demand as one of the motivations for FDI (Hervé-Mignucci and Wang, 2015). Few researchers have framed such investments and contracts as a response to the stringent domestic environment and climate policies, leading to less attention to the heterogenetic responses within power companies and the electricity industry.

Against this backdrop, this chapter aims to frame their foreign investments and contracts in sustainability transitions of the socio-technical regime, to explore the scale of geographical diversification and possible displacement of $\mathrm{CO}_{2}$ emissions.

The remainder of the chapter is organized as follows: Section 2 develops an analytical framework for identifying and understanding heterogenetic responses to the stringent environment and climate policy within the 
electricity sector while considering Chinese supporting policies for FDI; Section 3 shows the methodology and data collection strategy; Section 4 provides the results of the analysis; Section 5 discusses the underlying factors of the results to obtain implications of China's investments and contracts in foreign power projects on the displacement of $\mathrm{CO}_{2}$ emissions; and Section 6 concludes and provides perspectives and remaining challenges for the remaining chapters and further research.

\section{Analytical framework}

\subsection{Direct and indirect effect of stringent environmental and climate policy}

Impacts of stringent environmental and climate policy can be categorized as direct and indirect impacts (Zhao et al., 2020). Direct effects of emission reduction refer to emission reduction through exiting or pollution abatement investments by pollution and carbon-intensive industries (Zhao et al., 2020). Indirect effects refer to changes in emissions by inducing the relocation of carbonintensive industries and the location of new carbon-intensive industries. The relocation of carbon-intensive industries is more likely to occur for industries and companies in highly competitive markets and with few state interventions that benefit them, such as sufficient pass-through rates and larger free allocation of allowances in the emission trading scheme (Zheng and Shi, 2017).

The indirect effects generate two opposing results. On the one hand, they reduce emissions in host countries. Industrial relocation can usher in advanced and/or cleaner technologies for production and generate pollution and the carbon halo effect. Empirical studies have found the less polluting effect (Eskeland and Harrison, 2003), and even halo effect in selected Middle East and North African countries (Asghari, 2013). It is more likely to be generated when host countries have a wide technological gap against countries with stringent environmental and climate policy but a high-skilled labor force (Zugravu-Soilita, 2017) and high learning efficiencies (Dean et al., 2009).

On the other hand, the indirect effects increase emissions. Relocation of pollution or carbon-intensive industries are accompanied by the relocation of emissions, generating pollution, and carbon haven effect. Some empirical tests have shown that the carbon haven effect dominates the carbon halo effect in Latin American countries (Sapkota and Bastola, 2017), sub-Saharan Africa (Kivyiro and Arminen, 2014), Ghana (Solarin et al., 2017), the Association of Southeast Asian Nations' countries (Baek, 2016), and China (Arce et al., 2016; Ren et al., 2014). In China, provinces with worse governance have observed not only relocation of carbon-intensive sectors, increased output and consumption of carbon-intensive sectors, and $\mathrm{CO}_{2}$ emissions but also the move-out of value added to provinces with better governance, improving the economic performance of the latter (Wang et al., 2019).

An institutional gap can also affect the relative magnitude between pollution and the carbon haven and halo effects because environmental standards, 
corruption, and democracy can affect the location and environmental behavior of multinational companies (Eskeland and Harrison, 2003; Solarin et al., 2017). In host countries where institutions are more developed and environmental management capabilities are strong, relocated industries and new investors are likely to adopt global environmental standards, invest in more environmentally friendly technology, and act more responsibly in waste generation and management (Christmann, 2004). This results in an improvement in the overall environmental quality of host countries and cities (Wang and Chen, 2014). In contrast, relocated industries, new investors, and political elites in host countries and regions may engage in opportunistic behavior at the expense of the environment (Wang and Chen, 2014), where governance and institutions are weaker because of corruption and financial reasons (Millimet and Roy, 2015). Profit-driven dirty industries are attracted, especially by developed countries (Candau and Dienesch, 2017), while loosened enforcement of environmental regulations can hardly control their polluting practices effectively. Host country governments also do not increase public expenditure for the environment and its contribution to the accumulation of pollution abatement capabilities, as long as they allow foreign firms to control technologies (Dean et al., 2009).

Although the categorization is useful in elaborating how the two opposing results are generated, it does not sufficiently explain the types of incumbent companies and their challenges and perceptions that cause indirect environmental effects through their relocation and investments in foreign countries (Turnheim and Sovacool, 2020). Incumbent companies have important structural differences such as the structure of complexes, regional positioning, and stakeholder structure, which generate different damages from the same external pressures (Kungl, 2015). They pursue their goals and have their decision-making styles, scales of operations, and technologies with their different dynamics, time horizons, and speeds of development (Markard and Hoffmann, 2016). Stringent environmental and climate policies would have different effects on incumbent companies. Incumbent companies with different attributes are expected to show various responses to the policies. Incumbent companies in service sectors may not cause significant environmental effects by their relocation and investments in foreign countries (Al-mulali and Tang, 2013).

\subsection{Polices and measures for industrial relocation}

The Chinese government's going global strategy and the BRI can be considered strategies for international industrial relocation. Although the BRI is more an economic diplomatic tool to advance these diplomatic and strategic objectives (Blanchard, 2017), both aim to encourage companies to export their products and services in the international market, invest in foreign countries to acquire stakes and assets in resource mining, gain technical know-how, and streamline management capabilities. Among them, coal power is identified as a strategic investment for international development and state support. This is a sector through which Chinese technology, 
equipment, and services can be exported, particularly as domestic deployments taper off.

By contrast, investors and contractors encounter high country risk and international geopolitics, especially in host countries perceived as a security risk to their invested projects (Feng et al., 2020). This risk ranges from the credit risk of contracted firms, commercial risk, and fuel supply risk to risks associated with political and regime changes and subsequent legal and regulatory changes, local conflicts caused by land appropriation, conflicts of interests among stakeholders, adverse impacts on environment, society and culture, and other force majeure such as disasters, wars, riots, and lockouts.

To assist the implementation of the going global strategy and the BRI, the State Council provided guidance in 2015 to provide export credit or other favorable financing terms for EPC contracts or equipment purchases; build, operate, and transfer (BOT) models; and public-private partnerships (PPPs; Hervé-Mignucci and Wang, 2015). CHEXIM and CDB, in coordination with the National Development and Reform Commission, established "special loans" and "equity loans" for foreign investments. Apart from state ownership, the Chinese government capitalizes on the human resources management of the Communist Party of China (CPC) and coordination between its energy-germane and finance-germane bureaucracies, to maintain the alignment between these policy banks and state energy companies (Kong and Gallagher, 2017). Tying financing with business deals for Chinese companies enabled some companies in the declining domestic coal industry to revitalize (Shearer et al., 2019).

Nonetheless, these financial supports are insufficient to motivate FDI in the energy sector. Both Chinese investors and financial institutions are engaged with countries with higher country risk ratings and are thus exposed to higher country and macroeconomic risks. Even the resource-backed infrastructure model has not significantly reduced risks because of the decrease in commodity prices and associated macroeconomic downturns in the developing world (Gallagher et al, 2018).

For these reasons, Chinese investors and banks demanded higher interest payments (LGS Online, 2009) and a full guarantee for the credit risk of a state-owned utility, from the Ministry of Finance (Ali, 2009; Castle and Manuwoto, 2011), as a condition to make loans to coal power projects. However, these unfavorable terms of conditions generated repercussions in host countries, prolonging negotiations. Alternatively, host countries adopted PPPs such as BOT schemes that can shift financial risk to independent power producers (IPPs), in exchange for allowing them to join projects as investors and provide operation and maintenance (O\&M) services in the long run.

In response, the Chinese government established standardized procedures for EPC contracts. First, policy banks conclude a framework agreement with a host country's ministry of finance and then ask the ministry for a letter of application, an EPC contract with a Chinese company, a project feasibility study, and an environmental impact assessment. Next, a Chinese importer signs a purchase agreement with the company selling the commodity, and Chinese 
policy banks sign a loan agreement with the host country government and create an escrow account into which the proceeds from a specified amount of the export are deposited to ensure the repayment of the EPC contract loan in cash, not in commodity (Brautigam, 2009; Brautigam and Gallagher, 2014).

China also employs the common fate and destination model of an infrastructure finance model that underscores common interests between both China and the host country, to manage country and macroeconomic risk in greenfield investments. The key actor in this model is a joint venture established between a Chinese state-owned enterprise and a host company. The venture takes advantage of cost competitiveness and the close relationship with the government to convince the government to host favorable biddings to them, as well as move earlier to address policy changes. When winning a bid, the company mobilizes financing from Chinese institutions by combining export buyer credits and non-concessional loans. These syndicated loans are often tied to the services provided by the company that wins a bid (Lin and Wang, 2017). The company may invite host country counterparts to offer a minor portion of a stake or asset to ensure full ownership of host country governments. Take-or-pay clauses with a state-owned utility have become prevalent to secure the minimum rate of return, assuming that most host countries have a state-owned utility in charge of the transmission, distribution, and supply of electricity and billing to customers.

The Chinese government has also agreed to larger investment framework agreements with an increasing number of host country governments. With Brazil, the government began with the mechanisms of bilateral dialogue and upgraded to the High-Level Concertation and Cooperation Commission in 2004 to enhance the linkage between industries in both countries. In 2009, the two countries signed a Joint Action Plan, which boosted Chinese investments not only in greenfield investments such as steel plants, shipyards, automobile plants, gas pipelines, and railway projects but also in brownfield investments: acquisition of electricity, petroleum extraction, and steel companies (Cardoso, 2013). In 2015, both countries agreed to create the Brazil-China Cooperation Fund for the Expansion of Production Capacity, with envisaged funding of US\$20 billion, of which US\$15 billion was from the China-Latin America Investment Cooperation Fund (CLAI Fund), expecting that these funds would induce other Chinese companies to make greenfield investments.

In 2015, the Chinese government also agreed to the China-Pakistan Economic Corridor (CPEC), a collection of infrastructure projects in Pakistan supported by Chinese funding; in the same year, it signed the ChinaIndonesia agreement on the cooperation in the construction of power plants, as well as in the planning, construction, operation, and maintenance of electrical grids (the People's Republic of China and the Republic of Indonesia, 2015).

Perceiving the development of these risk management schemes at the national level, Chinese incumbent power companies increase contracts and make greenfield investments in power projects, including coal power in these 
countries. Huaneng invests in the Sahiwal coal power plant; State Power Investment Corporation (SPIC) invests in the Hubco power plant in Pakistan; and Huadian, Shenhua, and Datang invest in building and operating coal power plants in Indonesia. As a result, of the $102 \mathrm{GW}$ supported by Chinese finance, $30 \mathrm{GW}$ involve joint ownership arrangements with Chinese state-owned enterprises, and an additional $11 \mathrm{GW}$ are BOT arrangements (Shearer et al., 2019: 7).

\section{Methodology and data collection strategy}

\subsection{Research design and case selection}

We adopt a case study strategy with single-case, embedded designs. A case study is more suitable than other methods for studies whose research questions are "how" and "why" and whose focus is more on contemporary, and not entirely historical, phenomena than on other methods (Yin, 2014).

We take the "Big Five" state-owned power generation utility groups: Huaneng, Guodian, Huadian, Datang, and SPIC; two other large stateowned power groups of the State Development and Investment Corporation and China Resources (Huarun); two state-owned grid companies, State Grid Corporation of China and China Southern Power Grid; and two stateowned major coal power-integrated companies, Shenhua and China Coal, as cases of regulated incumbent power companies. The selection logic is that they were mandated to upgrade and renovate coal power plants to either ultra-supercritical plants with the capacity of more than $600 \mathrm{MW}$ or supercritical, fluidized bed plants with the capacity of more than $300 \mathrm{MW}$, and high efficient fuel gas desulfurization and denitrification equipment in $2014^{2}$ as a part of the 2013 Air Pollution Prevention and Control Action Plan. Because Huaneng becomes the largest shareholder of Shenzhen Energy and the State Grid of Shandong Electric Power Corporation, we treat these two companies as subsidiaries of the Huaneng group.

Readers might at first consider it odd to exclusively select state-owned power groups for comparison because China uses a top-down and nonparticipatory approach to public policy making (Gilley, 2012). In addition, the CPC can exercise its power over personnel to allocate a higher position in the country's political hierarchy to leaders in state-owned enterprises with better performances, incentivizing them to comply with government priorities (Kong and Gallagher, 2017). Nonetheless, we expect heterogeneity in geographical diversification among the regulated state-owned power utilities because they showed heterogenic responses to the stringent regulations in the domestic market (Mori, 2020).

To analyze the scale of investments and contracts by the regulated incumbents, we compare these "regulated incumbents" with those of other Chinese companies who invest and win contracts in foreign power projects. Chinese power companies are categorized into four groups: (a) incumbent 
power generators not subject to the stringent regulation (unregulated incumbents); (b) incumbent power equipment manufacturers who organize projects as investors or sign contracts as suppliers (incumbent power manufacturers); (c) renewable energy goods manufacturers who invest not only in greenfield wind and solar power projects but also in new manufacturing plants (renewable energy manufacturers); and (d) developers of coal power plants, that is, engineering and construction companies (project developers; Table 5.1).

Table 5.1 Chinese companies invested and contracted in foreign power projects by types

\begin{tabular}{|c|c|c|c|c|}
\hline $\begin{array}{l}\text { Incumbent power generators } \\
\text { and grids under the stringent } \\
\text { regulation }\end{array}$ & $\begin{array}{l}\text { Incumbent power generators } \\
\text { not subject to the stringent } \\
\text { regulation }\end{array}$ & $\begin{array}{l}\text { Incumbent power } \\
\text { equipment } \\
\text { manufacturers }\end{array}$ & $\begin{array}{l}\text { Renewable } \\
\text { energy } \\
\text { manufacturers }\end{array}$ & Project developers \\
\hline Huaneng & China Three Gorges (CTG) & Dongfang Electric & Wind power & $\begin{array}{l}\text { China Energy Engineering Group } \\
\text { Corporation }(\mathrm{CEEC})\end{array}$ \\
\hline Shenzhen Energy & $\begin{array}{l}\text { China International Water \& } \\
\text { Electric Corporation }\end{array}$ & Harbin Electric & $\begin{array}{l}\text { Envision } \\
\text { Energy }\end{array}$ & $\begin{array}{l}\text { China Power Engineering Consulting } \\
\text { Group Corporation (CPECC) }\end{array}$ \\
\hline $\begin{array}{ll}\text { Lancang } & \text { River } \\
\text { Hydropower } & \\
\end{array}$ & China Yangtze Power & Shanghai Electric & Goldwind & China Gezhouba Group \\
\hline $\begin{array}{l}\text { China Energy Investment } \\
\text { Corporation }\end{array}$ & $\begin{array}{l}\text { China National Nuclear } \\
\text { Corporation }\end{array}$ & $\begin{array}{l}\text { Tebian Electric } \\
\text { Apparatus }\end{array}$ & Ming Yan & $\begin{array}{l}\text { Power Construction Corporation of } \\
\text { China (POWERCHINA) }\end{array}$ \\
\hline Guodian & $\begin{array}{l}\text { China General Nuclear Power } \\
\text { Group }\end{array}$ & & Solar power & $\begin{array}{l}\text { Shandong } \quad \text { Electric } \quad \text { Power } \\
\text { Construction } \\
\text { Corporations (SEPCO I, II, III) }\end{array}$ \\
\hline Shenhua & & & BYD & Sinohydro \\
\hline Huadian & & & Comtec Solar & $\begin{array}{l}\text { China National Machinery Industry } \\
\text { Corporation (SINOMACH) }\end{array}$ \\
\hline Huadian Engineering & & & JA Solar & $\begin{array}{l}\text { China Machinery Engineering } \\
\text { Corporation (CMEC) }\end{array}$ \\
\hline Datang & & & Jinco Solar & $\begin{array}{l}\text { China National Electric Engineering } \\
\text { Corporation (CNEEC) }\end{array}$ \\
\hline State Power Investment & & & Longi & China National Heavy Machinery \\
\hline Corporation (SPIC) & & & & Engineering Corporation (CHMC) \\
\hline $\begin{array}{l}\text { China Power Investment } \\
\text { Corporation }\end{array}$ & & & Risen Energy & CITIC \\
\hline Shanghai Electric Power & & & Solargiga & China Communications Construction \\
\hline $\begin{array}{l}\text { State Nuclear Power } \\
\text { Technology Corporation }\end{array}$ & & & Suntech & \\
\hline Huarun/China Resources & & & Trina Solar & \\
\hline $\begin{array}{l}\text { State Development and } \\
\text { Investment Corporation } \\
(\text { SDIC })\end{array}$ & & & Zoenergy/ZTE & \\
\hline State Grid of China & & & Zongyi & \\
\hline $\begin{array}{l}\text { Shandong Electric Power } \\
\text { Corporation }\end{array}$ & & & & \\
\hline $\begin{array}{lr}\text { China Electric } & \text { Power } \\
\text { Equipment } & \text { and } \\
\text { Technology } & \\
\end{array}$ & & & & \\
\hline \multicolumn{5}{|l|}{ Southern Power Grid } \\
\hline China Southern Power & & & & \\
\hline
\end{tabular}

Note: Companies located in the second column are subsidiaries in the above first column. Source: The author's classification. 


\subsection{Data sources}

The Chinese Ministry of Commerce (MOFCOM) releases an FDI database on its website as the official Chinese source; it discloses individual transactions that cover 2,922 investments and contracts and provides the project name, date of transaction, host country, amount of investment, and installed capacity since $2012 .^{3}$ However, MOFCOM's annual data are always significantly revised because of unsteady reinvestments (Scissors, 2020); in addition, it does not cover all the projects while uploading projects under a pipeline or bidding process, such as the Ladakh solar project in India. For these reasons, its database is not reliable enough to conduct quantitative analysis.

In response, several institutions and research groups have used various strategies to estimate China's foreign transactions. The China-Africa Research Institute of Johns Hopkins University created a database on Chinese loan commitments to African governments for their analysis of the impacts of China's resource-backed finance in Africa (Brautigam, 2009), and keeps updating the database (Brautigam et al., 2019). However, it covers projects financing exclusively to African countries.

In collaboration with the China-Africa Research Institute, the Global Development Policy Center of Boston University expands the scope of China's energy finance globally by collecting and assembling the energy finance by China's two major policy banks, CDB and CHEXIM, in 2000-2019 (Gallagher, 2018a). The Center's dataset sorts the database into greenfield and brownfield investments to uncover different features within Chinese global energy finance (Kong and Gallagher, 2017). The dataset also estimates the impacts on the carbon footprint of China's global energy finance, by type of investments, by linking the energy finance database with attributes of each power plant described in (Li et al., 2020; Platts, 2015); however, it does not cover energy finance by state commercial banks, an investor's self-finance, and the newly created policy investment funds that aimed to advance the BRI, such as the Silk Road Fund (Gallagher et al., 2018). In addition, the dataset partially covers projects that Chinese companies join as EPC contractors.

By contrast, the College of William \& Mary, Development Gateway, and Brigham Young University have developed a more granular and comprehensive dataset on foreign assistance projects worldwide, especially those of China (Dreher et al, forthcoming); however, it covers only the years 20002014 and does not release the latest updates.

Finally, the American Enterprise Institute (AEI) has collected and assembled China's global investment and contracts in energy, transportation, real estate, and other major industries from 2005 to 2019 (American Enterprise Institute and the Heritage Foundation, 2020); it is the only fully public record that includes the amount, Chinese parent company, host country, and subsector, and is more reliable than the MOFCOM database. It also classifies Chinese investments into greenfield and brownfield and 
records the amount of transactions even when Chinese companies are involved only as contractors. ${ }^{4}$ However, it covers only those worth US $\$ 100$ million or more (Scissors, 2020) and does not provide project names and installed capacity. Because the database provides project information only by category of "energy" and "utility" sector, and type of energy, manual classification of projects are required to sort out projects in the electricity sector.

We considered these pros and cons of the database, and their fitness to the purpose of this research, and choose the AEI's China Global Investment Tracker as a core database. We select investments and contracts in the energy and utility sector and manually exclude transactions in resource extraction and transportation. Next, we use the project information in the China Electric Power Yearbook, Gallagher (2018b) and refer to Li et al. (2020), Endcoal (2020), and the Global Energy Monitor and Center for Media and Democracy (2020a) to identify project names, subsector (generation or grid), type of energy, installed capacity, category (greenfield or brownfield investments, contract), and financial institutions supporting the investments. Finally, we cross-check this database with primary sources such as company press reports and quarterly reports; reports from business journals, daily English newspapers such as Reuters, the South China Morning Post, China Daily, the Global Times, the Wall Street Journal, and local English newspapers in host countries to exclude projects that have not been implemented and to add projects not recorded. Documents are collected from online archives by searching for company and project names.

We use the amount of transactions as recorded in the AEI's China Global Investment Tracker. We understand that the differences between the planned and actual costs; delays in land acquisition, insufficient consideration to social and environmental impacts that causes local protests, and corruption are not unusual, and all these factors cause overcharging to host country governments. China Global Investment Tracker records these financial transactions only when it recognizes them as additional transactions. However, we have limited primary and secondary sources to ensure that these transactions are actually made and the recorded transactions are not redundant, because additional transactions are seldom released. This limitation leads us to exclude the recorded transactions with high uncertainty and classify transactions without a detailed description into "unidentified."

\section{Results}

\subsection{Heterogeneous responses among the type of companies}

All five types of companies collectively invest in and sign contracts for foreign power projects to the tune of US\$234 billion (Figure 5.1a) to increase installed capacity by 164 GW (Figure 5.1b) in 2014-2019. The amount of 


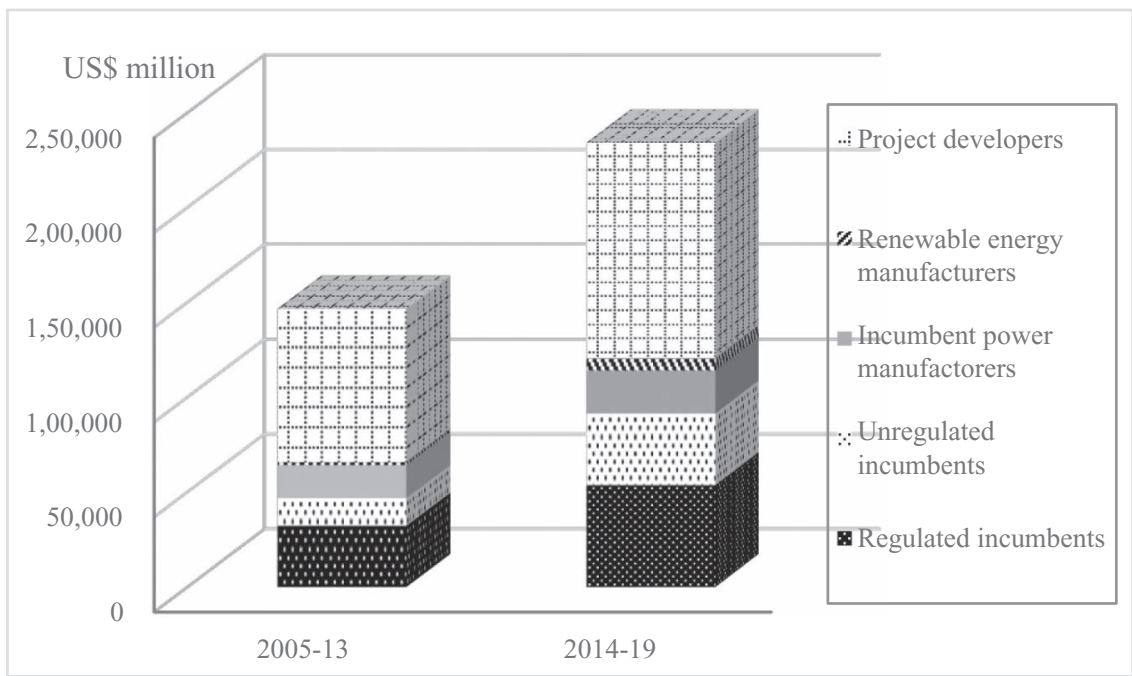

Figure 5.1a Amount of China's investments and contracts in foreign power projects. Source: Compiled by the author based on sources described in Section 3.2.

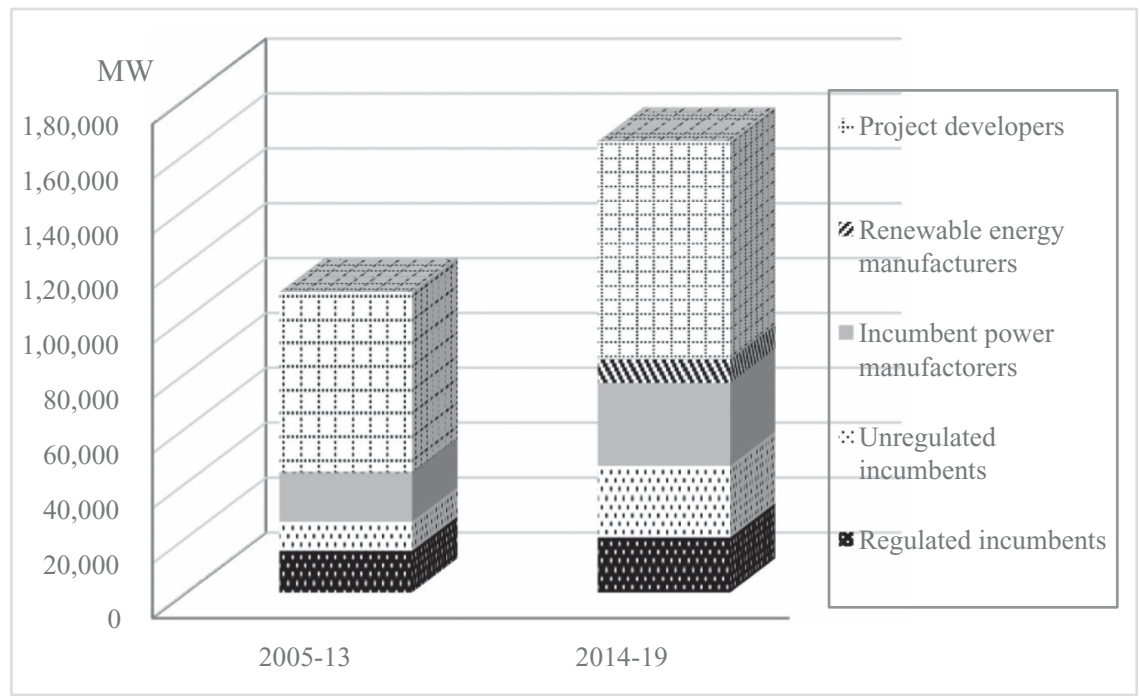

Figure $5.1 \mathrm{~b}$ Installed capacity by investments and contracts in foreign power projects.

Source: Compiled by the author based on sources described in Section 3.2.

the transaction increases by $60 \%$, and intended newly installed capacity increases by $50 \%$ in $2006-2013$. The new capacity amounts to $17 \%$ of the domestic new installed capacity in China $(853 \mathrm{GW})$ in the same period. ${ }^{5}$ 


\section{Akihisa Mori}

Coal power accounts for $24 \%$ in the amount of transaction or US\$57 billion (Figure 5.1c), and 33\% in the installed capacity or $54 \mathrm{GW}$ (Figure 5.1d), respectively. The new coal power capacity amounts to $21 \%$ of the domestic new installed coal power capacity in China $(249 \mathrm{GW})$ in the same period.

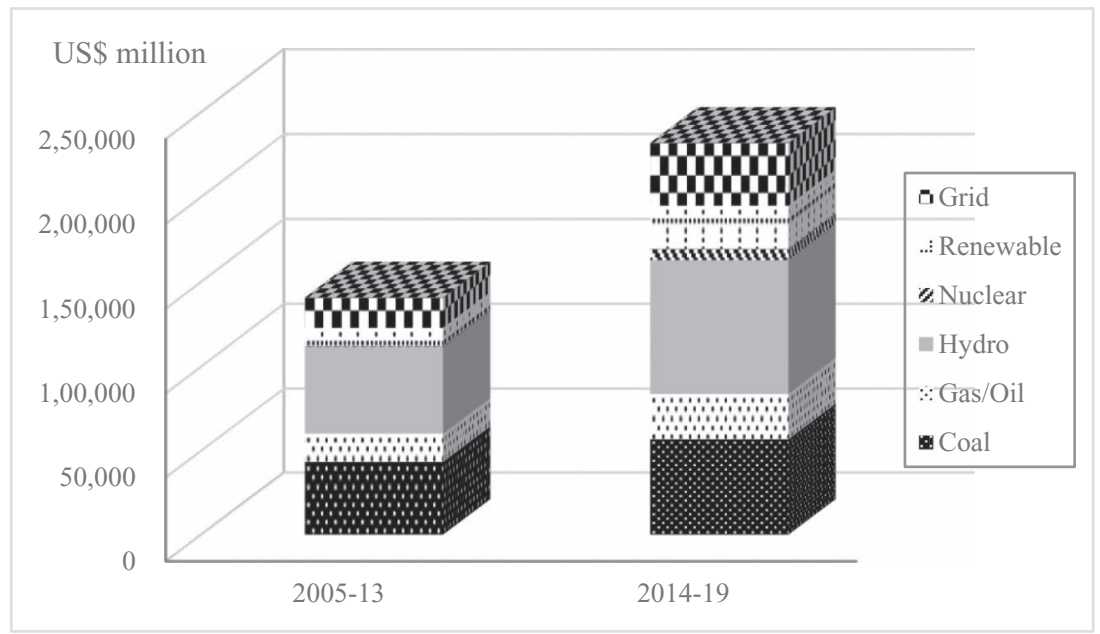

Figure 5.1c Amount of China's investments and contracts in foreign coal power projects.

Note 1: a contract consisting of capacity development of coal and renewable energy sourced power is classified into coal power.

Note 2: excluding transaction that cannot be identified.

Source: Compiled by the author based on sources described in Section 3.2.

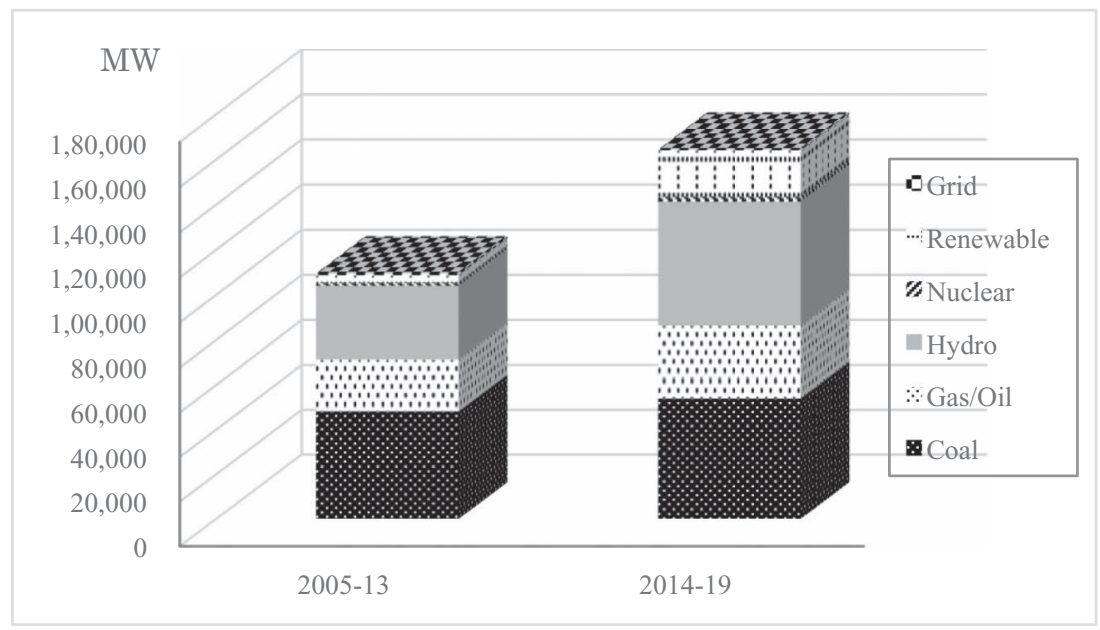

Figure 5.1d Installed capacity by China's investments and contracts in foreign coal power projects.

Source: Compiled by the author based on sources described in Section 3.2. 
Among the type of companies, project developers increase the most: US\$33 billion and $14 \mathrm{GW}$. The regulated incumbents are the third largest in the amount of a transaction and fourth in the installed capacity, with US\$21 billion and $5 \mathrm{GW}$, respectively. They increase greenfield investments in coal power (Figures 5.2a and 5.2b) and brownfield investments in grids (Figures 5.2c and 5.2d) and decrease contracts in coal power and grids (Figures 5.2e and 5.2f). As a result, they went through a slight increase in the share of the amount of transaction (from $22 \%$ to $23 \%$ ) but a decrease in the share of the installed capacity (from 14\% to 12\%) among the types of companies in 2014-2019.

By contrast, the unregulated incumbents increase brownfield investments in hydro and gas/oil power and contracts in nuclear power while slightly reducing greenfield investments in the same period. The incumbent power manufacturers increase contracts in coal power, and renewable energy ones increase greenfield investments in renewable energy (wind and solar power). Project developers increase contracts, especially those for grids, hydropower, and renewable energy. Although they also increase the amount of investments in coal and hydro power, the increased amount of contracts in the three subsectors outweighs the latter.

These results imply that the regulated incumbent utilities are the only type of companies that have shifted from contractors to investors, especially

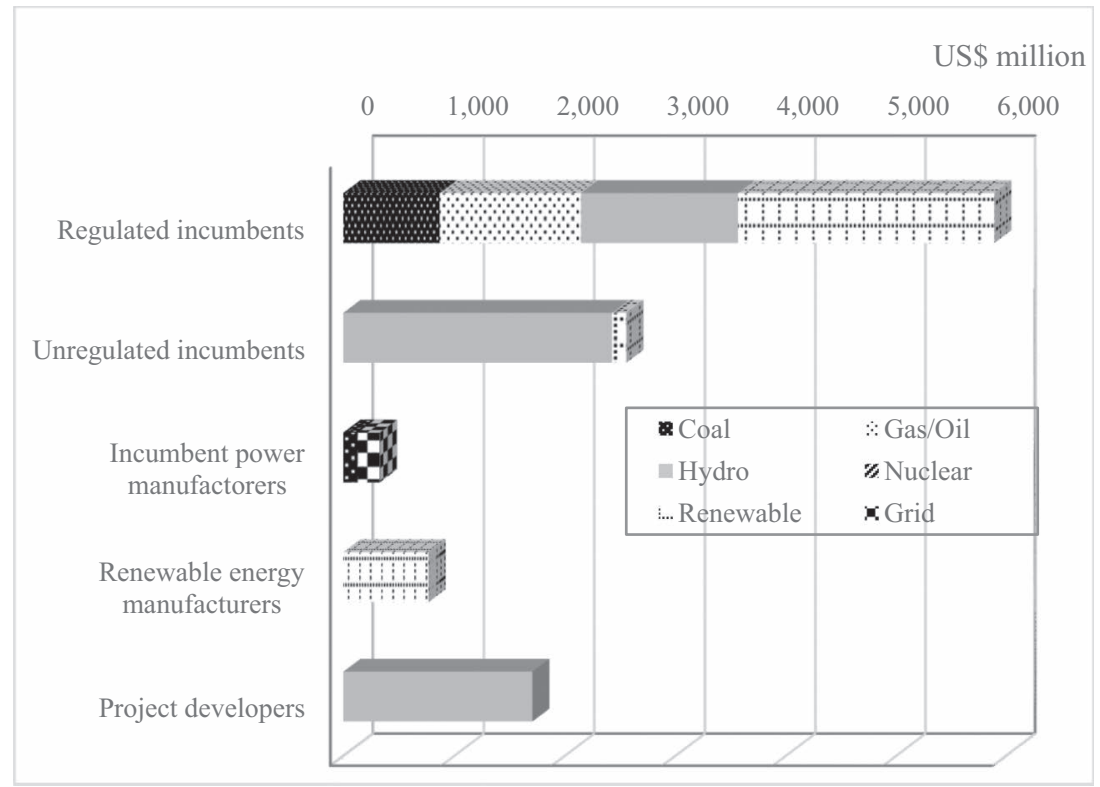

Figure 5.2a Amount of China's greenfield investments by category of companies and by type of energy in 2005-2013.

Source: Compiled by the author based on sources described in Section 3.2. 


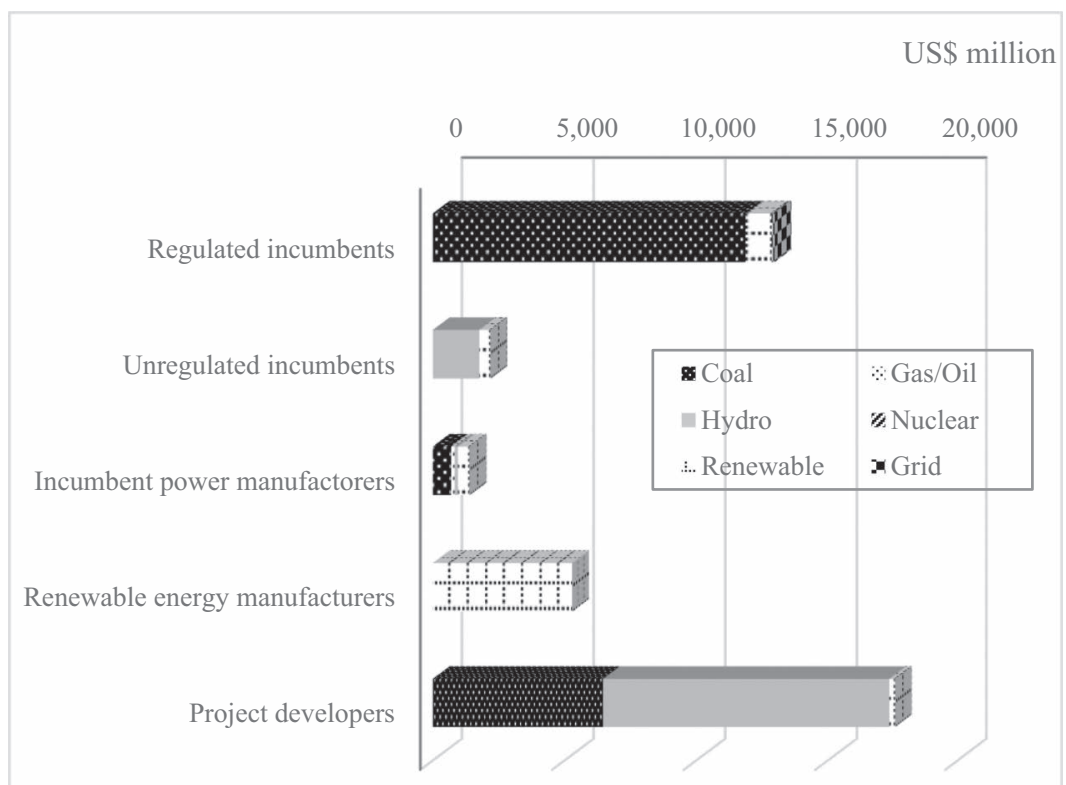

Figure 5.2b Amount of China's brownfield investments by category of companies and by type of energy in 2005-2013.

Source: Compiled by the author based on sources described in Section 3.2.

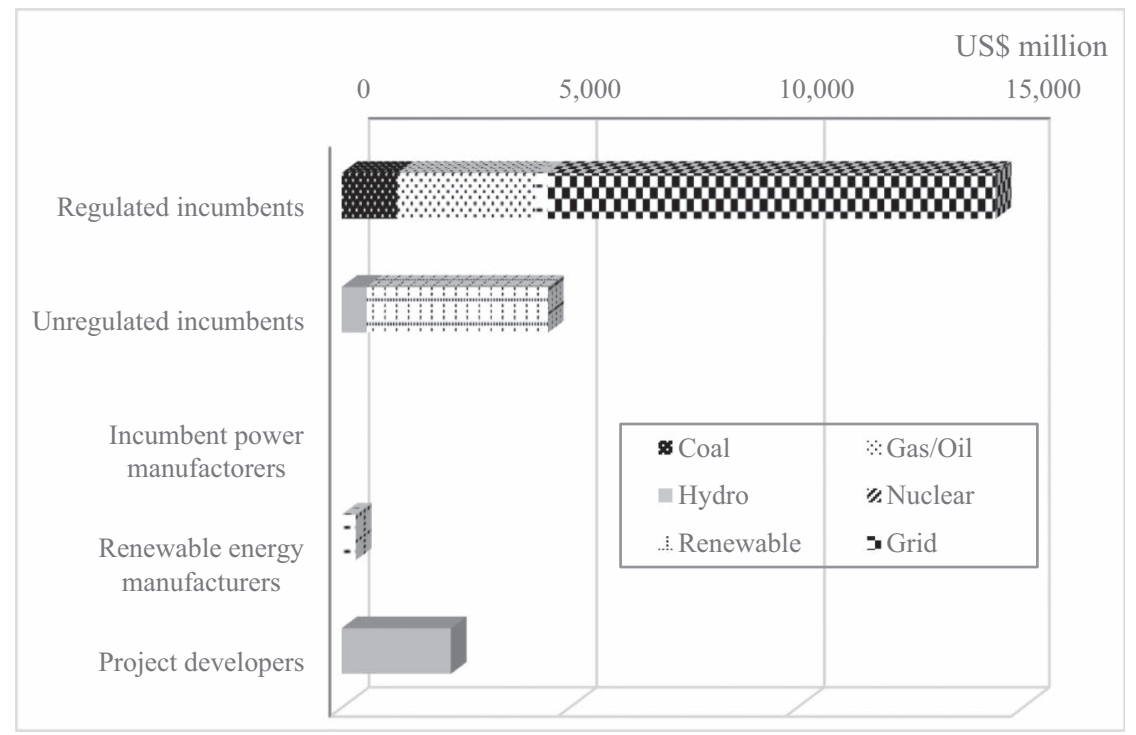

Figure 5.2c Amount of China's contracts by category of companies and by type of energy in 2005-2013.

Source: Compiled by the author based on sources described in Section 3.2. 


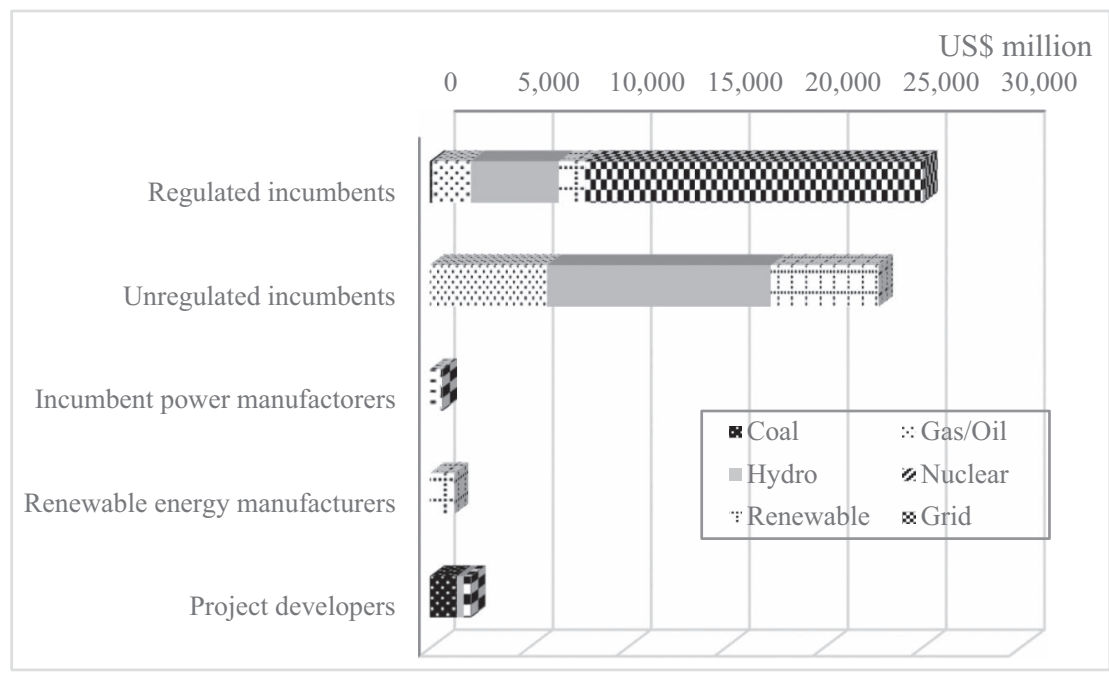

Figure 5.2d Amount of China's greenfield investments by category of companies and by type of energy in 2014-2019.

Source: Compiled by the author based on sources described in Section 3.2.

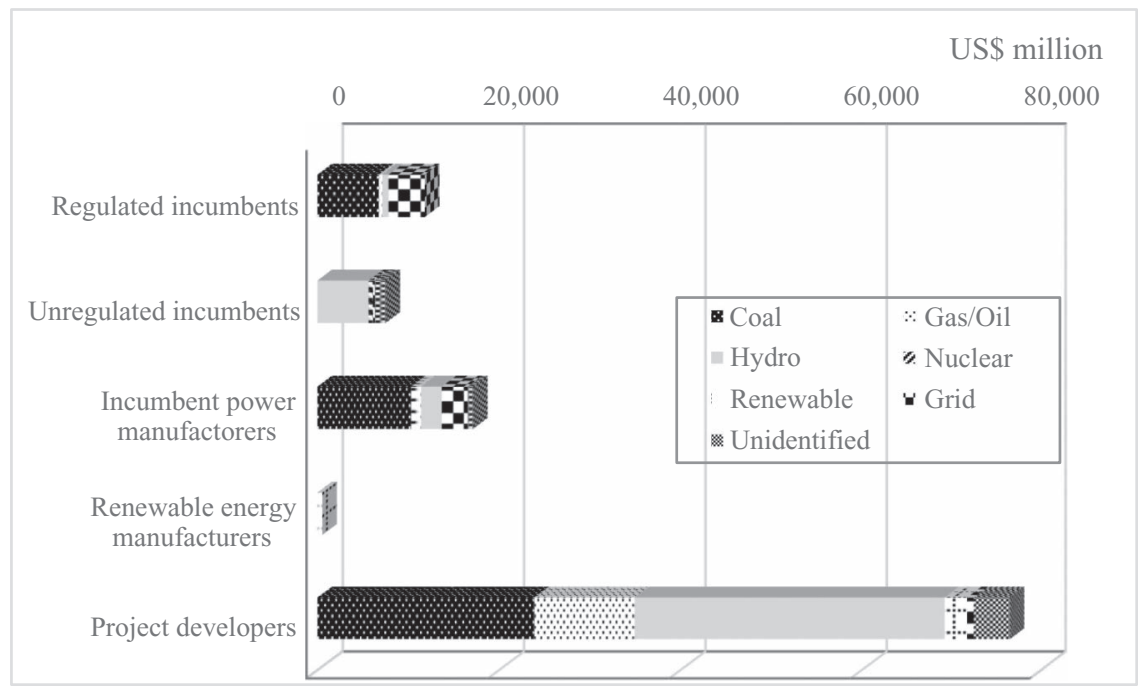

Figure 5.2e Amount of China's brownfield investments by category of companies and by type of energy in 2014-2019.

Source: Compiled by the author based on sources described in Section 3.2.

coal power and grids in 2014-2019. Renewable energy manufacture is another type of company that accounts for a larger amount in greenfield investments in 2014-2019, but they did not win any contracts in 2005-2013. 


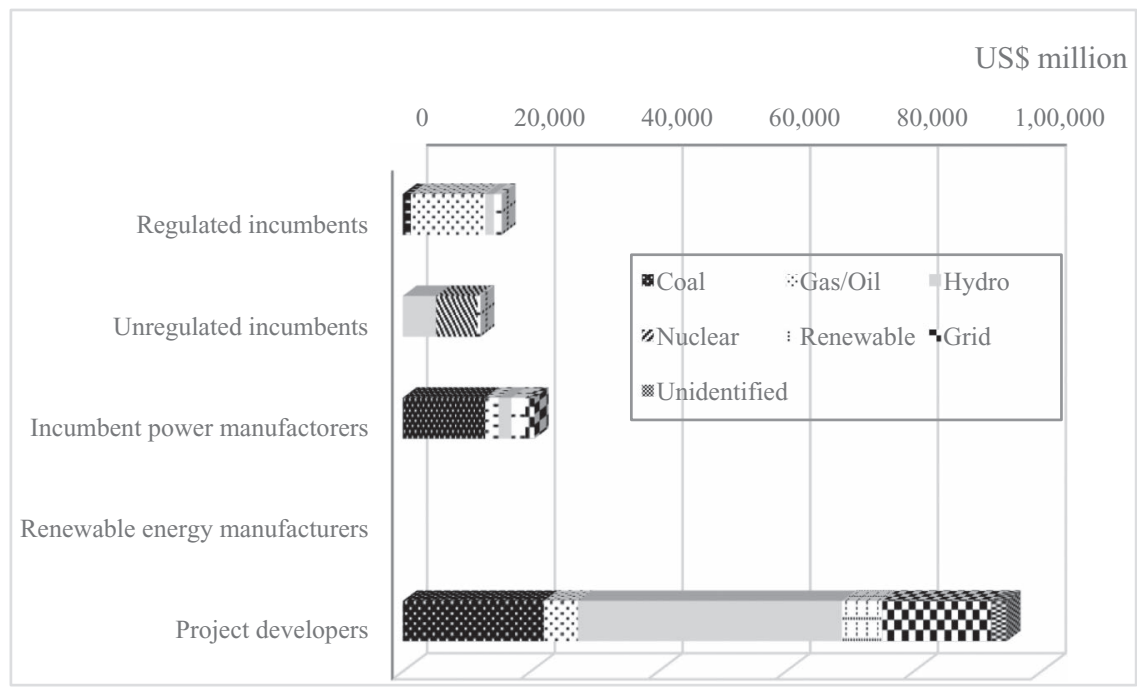

Figure 5.2f Amount of China's contracts by category of companies and by type of energy in 2014-2019.

Source: Compiled by the author based on sources described in Section 3.2.

\subsection{Mixed responses within the regulated incumbent power companies}

Among the regulated incumbents, SPIC, Southern Power Grid, Shenhua, and Huaneng increase greenfield investments by more than US\$1 billion in 2014-2019 (Figures 5.3a and 5.3b). Except for SPIC, all of them invest exclusively in coal power in this period. This finding demonstrates a sharp contrast in contracts, whereby they were awarded in a various types of energy in 2005-2013 while winning nothing in 2014-2019, except for Huadian (Figures $5.3 \mathrm{e}$ and 5.3f). These results imply that SPIC, Shenhua, and Huaneng have shifted from being contractors to greenfield investors in coal power.

In contrast, State Grid and Southern Power Grid increase the number of contracts, especially in renewable energy and grid projects (Figures 5.3e and 5.3f). Coupled with the shift of the regulated incumbent power generators to greenfield investments, the two grid companies account for a greater amount of contracts, which exceeds $80 \%$ in the amount of contracts held by the regulated incumbents.

State Grid, SPIC, and to a less extent Southern Power Grid, also increase brownfield investments in 2014-2019 (Figures 5.3c and 5.3d). However, they differ in the type of energy: two grid companies increase investments mostly in grids and in installed capacity of gas and renewable energy only when greenfield investment is an integral part of brownfield investment. By contrast, SPIC does so in hydro, gas, and renewable energy. 


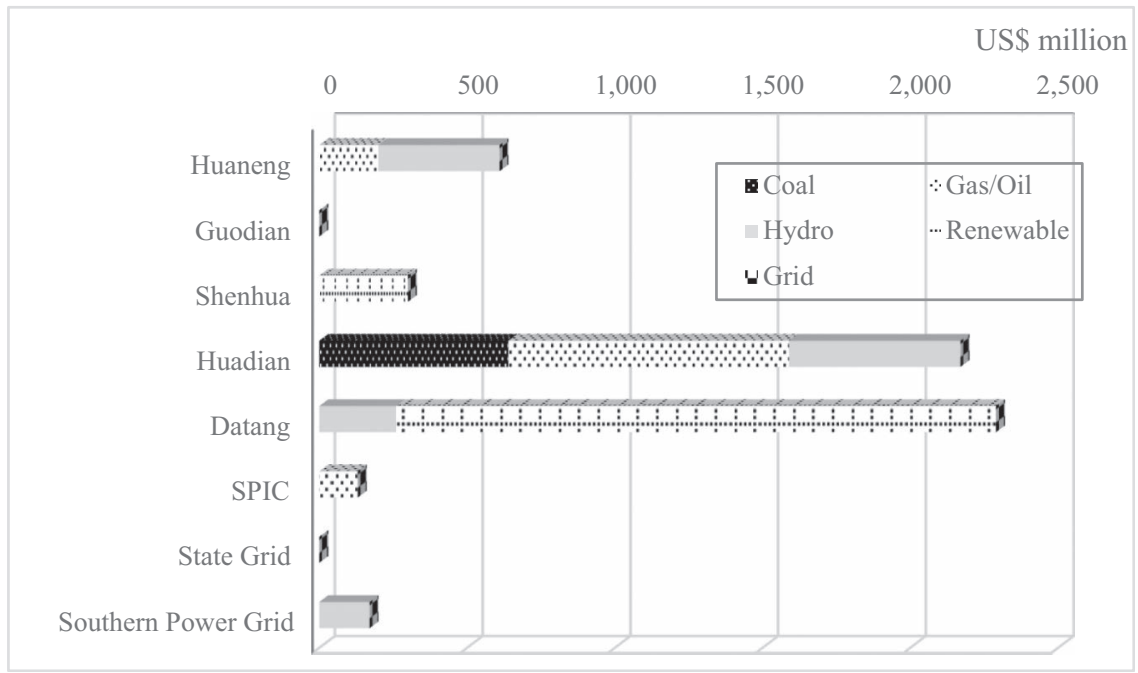

Figure 5.3a Amount of China's greenfield investments by the regulated incumbents and by type of energy in 2005-2013.

Note: Huaneng includes joint investments with Guangdong Yuadian, Datang with China South Industries, SPIC with State Grid, Southern Power Grid and AVIC, and State Grid with Power Construction Corporation.

Source: Compiled by the author based on sources described in Section 3.2.

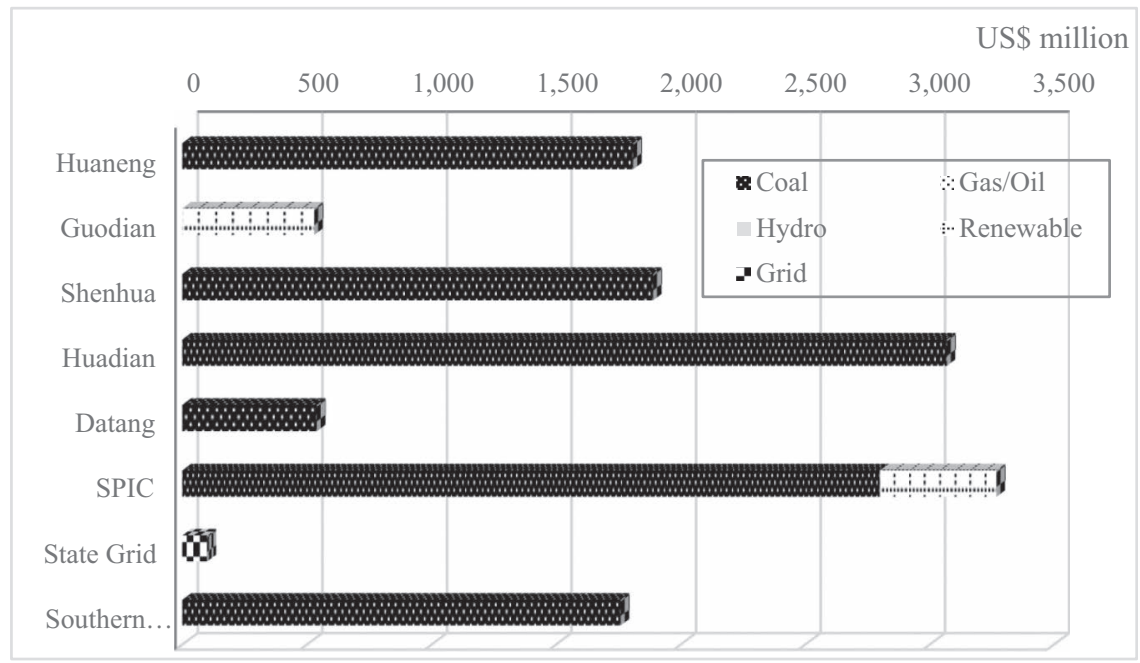

Figure 5.3b Amount of China's brownfield investments by the regulated incumbents and by type of energy in 2005-2013.

Source: Compiled by the author based on sources described in Section 3.2. 


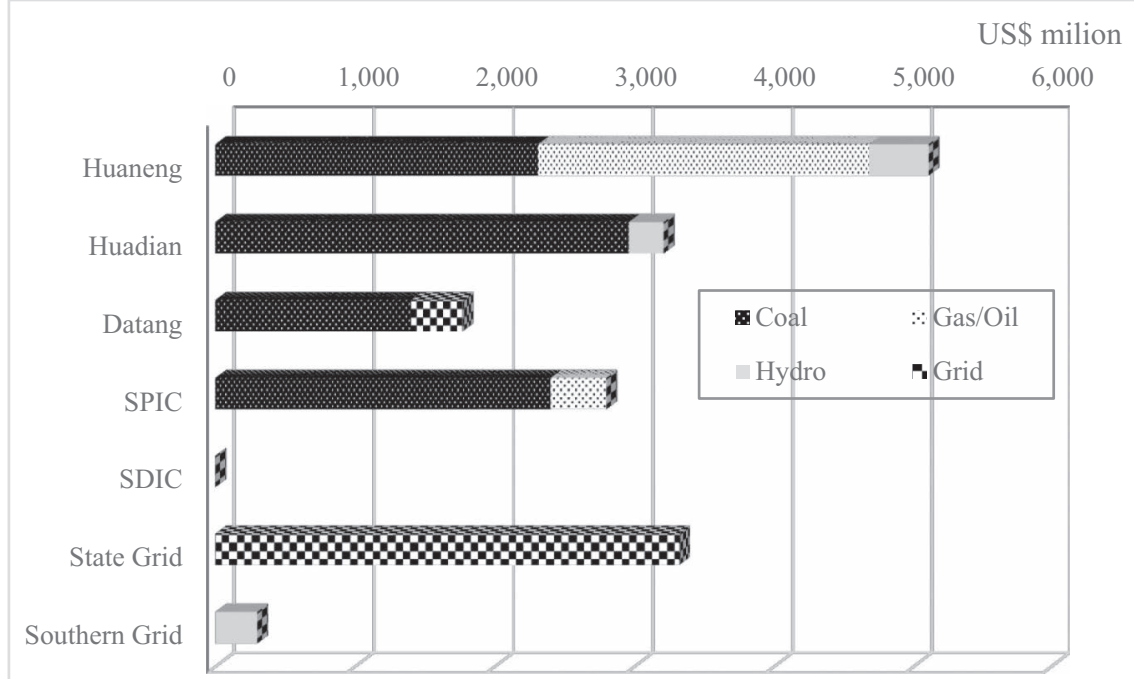

Figure 5.3c Amount of China's contracts by the regulated incumbents and by type of energy in 2005-2013.

Source: Compiled by the author based on sources described in Section 3.2.

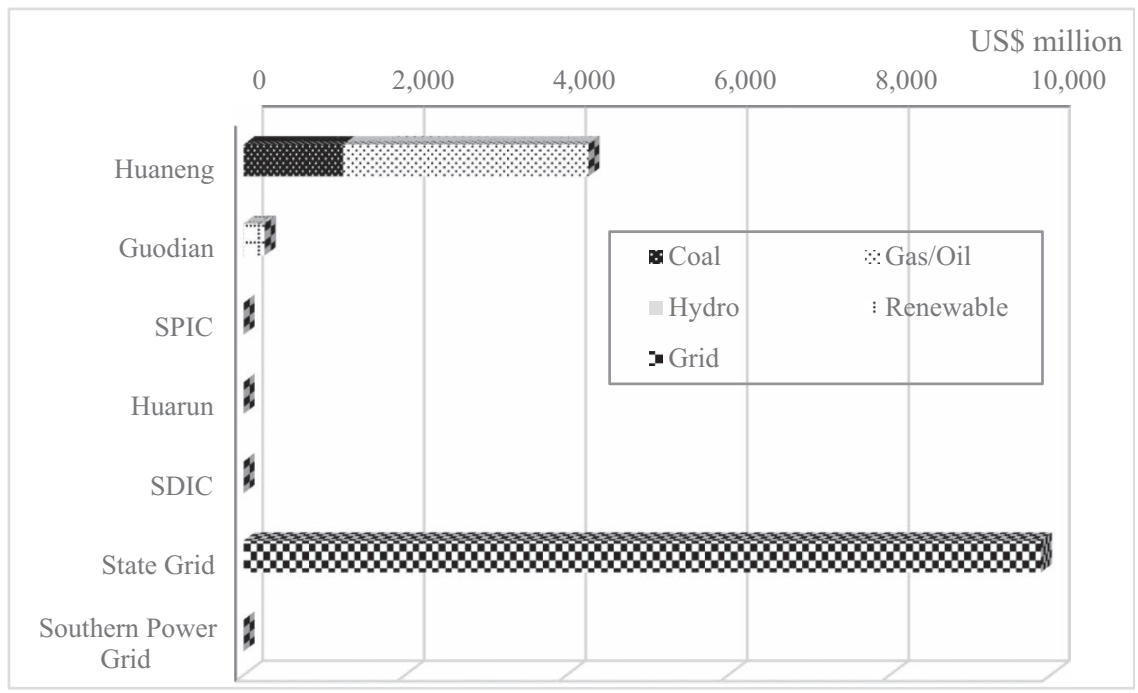

Figure 5.3d Amount of China's greenfield investments by the regulated incumbents and by type of energy in 2014-2019.

Source: Compiled by the author based on sources described in Section 3.2.

By contrast, Datang reduces both greenfield investment and contracts in 2014-2019. The company made the largest amount of greenfield investments in renewable energy in 2005-2013 but a much smaller amount in 2014-2019 because it does not win any contracts in this period. 


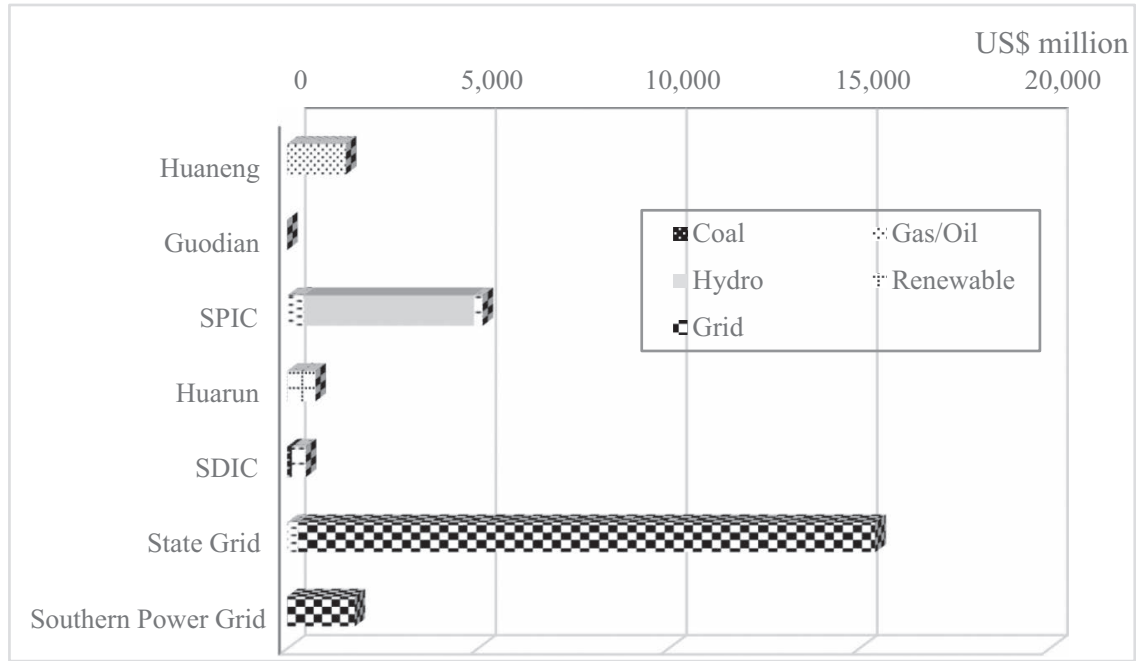

Figure 5.3e Amount of China's brownfield investments by the regulated incumbents and by type of energy in 2014-2019.

Source: Compiled by the author based on sources described in Section 3.2.

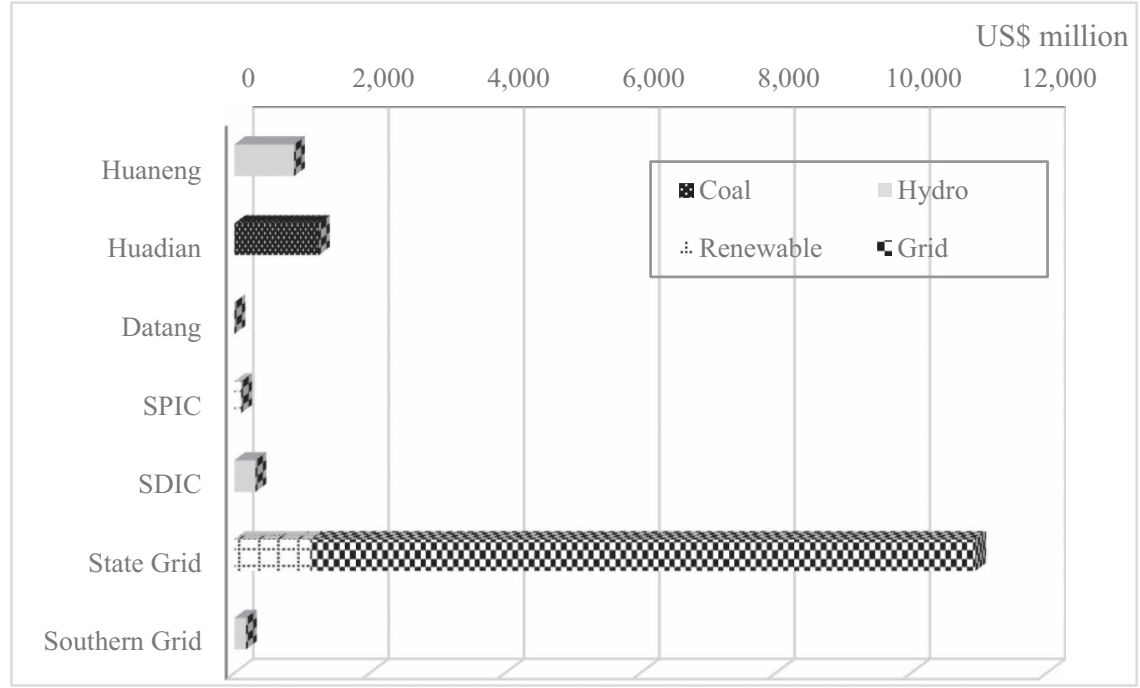

Figure 5.3f Amount of China's contracts by the regulated incumbents and by type of energy in 2014-2019.

Source: Compiled by the author based on sources described in Section 3.2.

\subsection{Heterogeneous selection of host countries}

The regulated incumbents show heterogeneity in the selection of host countries. The regulated incumbent power generators made greenfield investments and received contracts in a variety of host countries such as India, Turkey, 


\section{Akihisa Mori}

and Vietnam for various types of energy in 2005-2013 (Figures 5.4a and 5.4c). However, they concentrated them in coal power and only in six countries: Indonesia, Pakistan, Vietnam, Turkey, Cambodia, and Bangladesh (Figure 5.4d). This finding sharply contrasts with the regulated incumbent grid companies.

By contrast, the regulated incumbent grid companies made brownfield investments only in Australia, Brazil, the Philippines, and Portugal(Figure 5.4b)

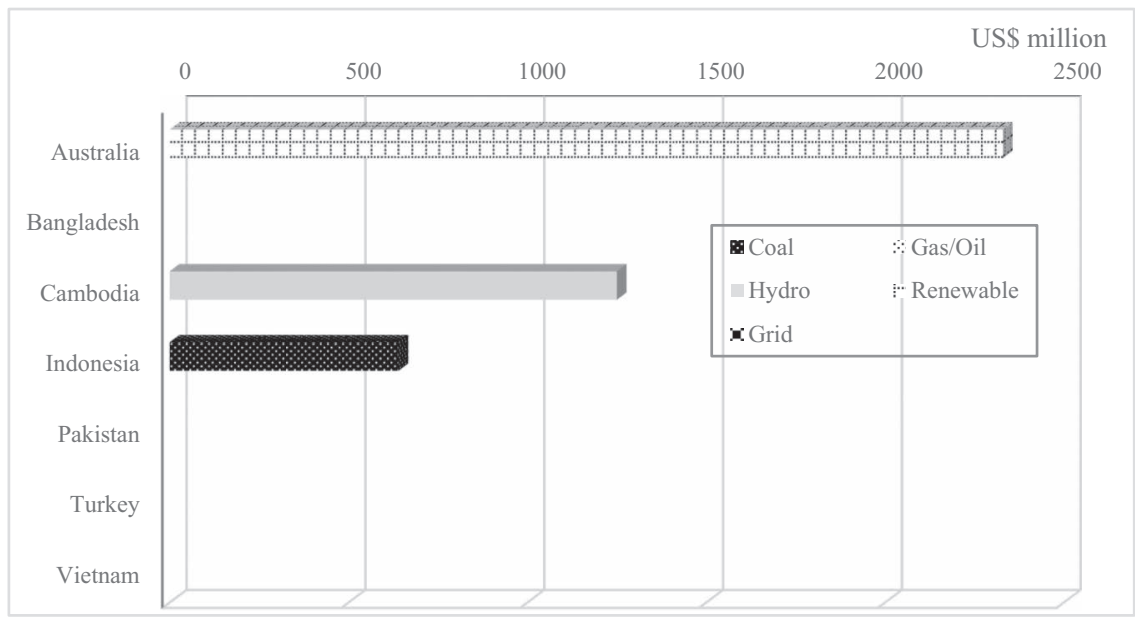

Figure 5.4a Amount of China's greenfield investments by host country and by type of energy in 2005-2013.

Source: Compiled by the author based on sources described in Section 3.2.

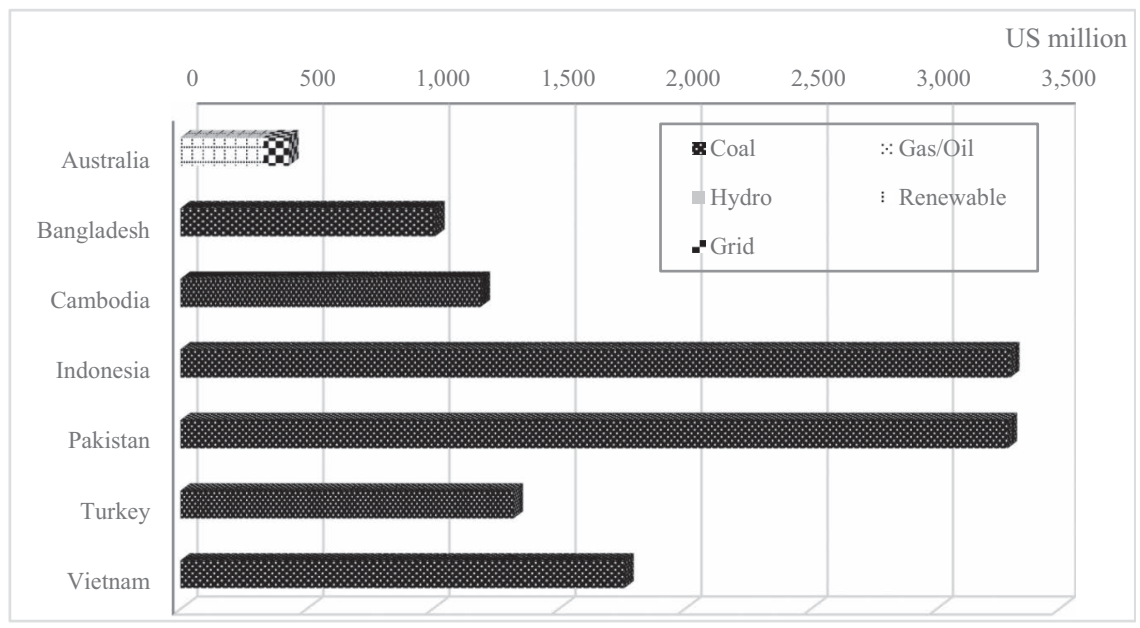

Figure 5.4b Amount of China's brownfield investments by host country and by type of energy in 2005-2013.

Source: Compiled by the author based on sources described in Section 3.2. 


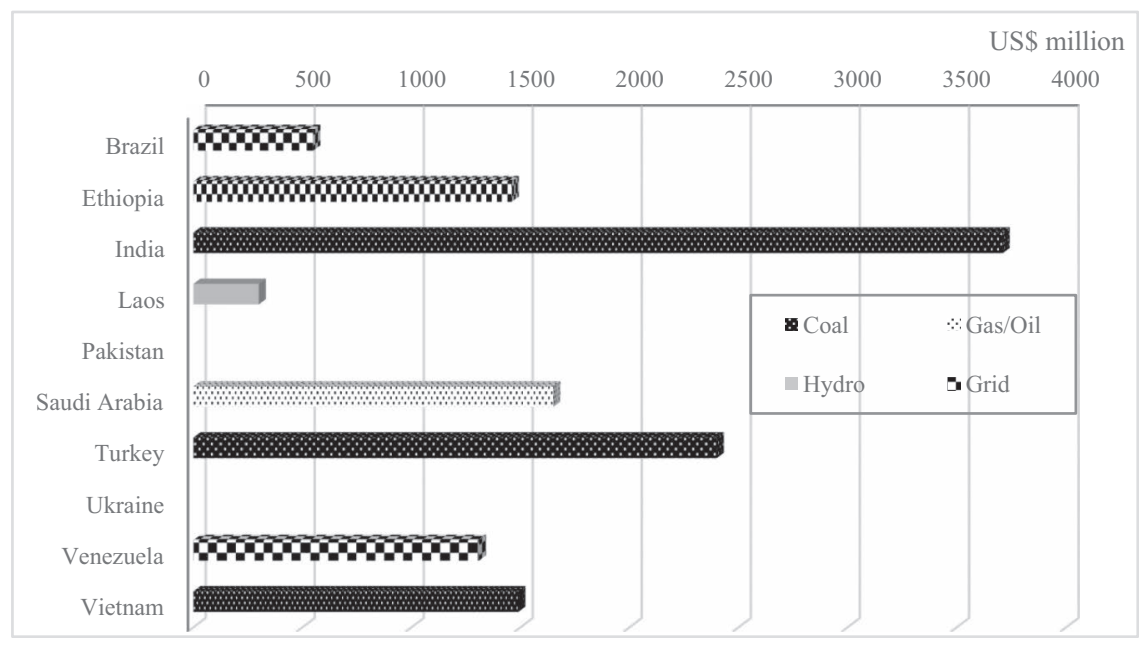

Figure 5.4c Amount of China's contracts by host country and by type of energy in 2005-2013.

Source: Compiled by the author based on sources described in Section 3.2.

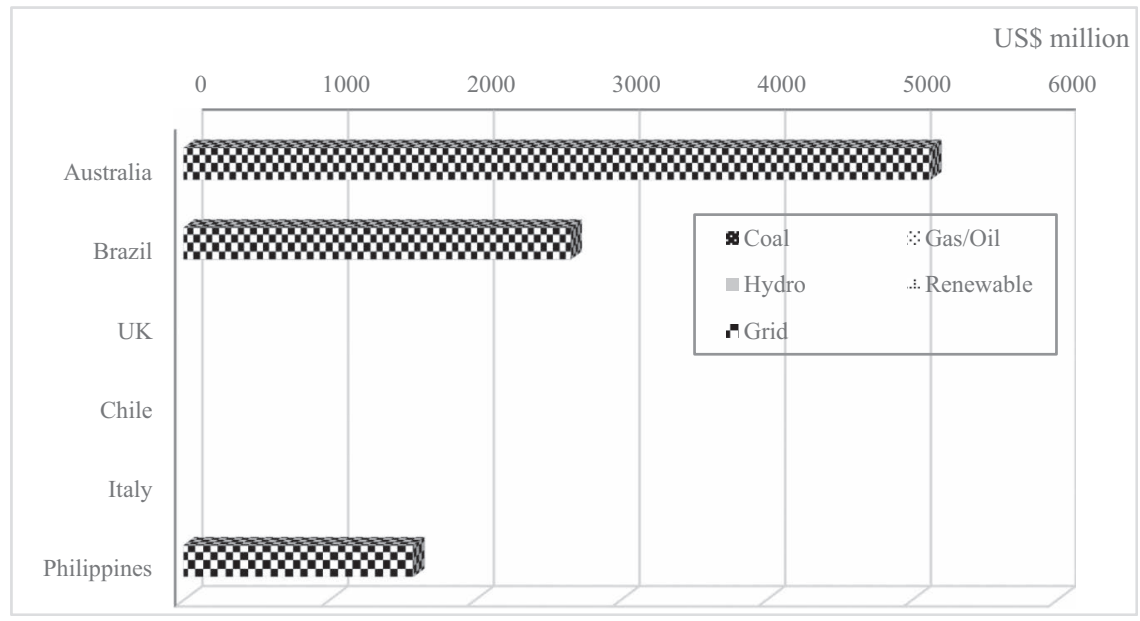

Figure 5.4d Amount of China's greenfield investments by host country and by type of energy in 2014-2019.

Source: Compiled by the author based on sources described in Section 3.2.

and contracts in Ethiopia and Venezuela in 2005-2013 (Figure 5.4c). However, they increase geographical diversification to Brazil, Chile, and Italy in brownfield investments (Figure 5.4e) and to Brazil, Pakistan, and Saudi Arabia in contracts in 2014-2019 (Figure 5.4f). 


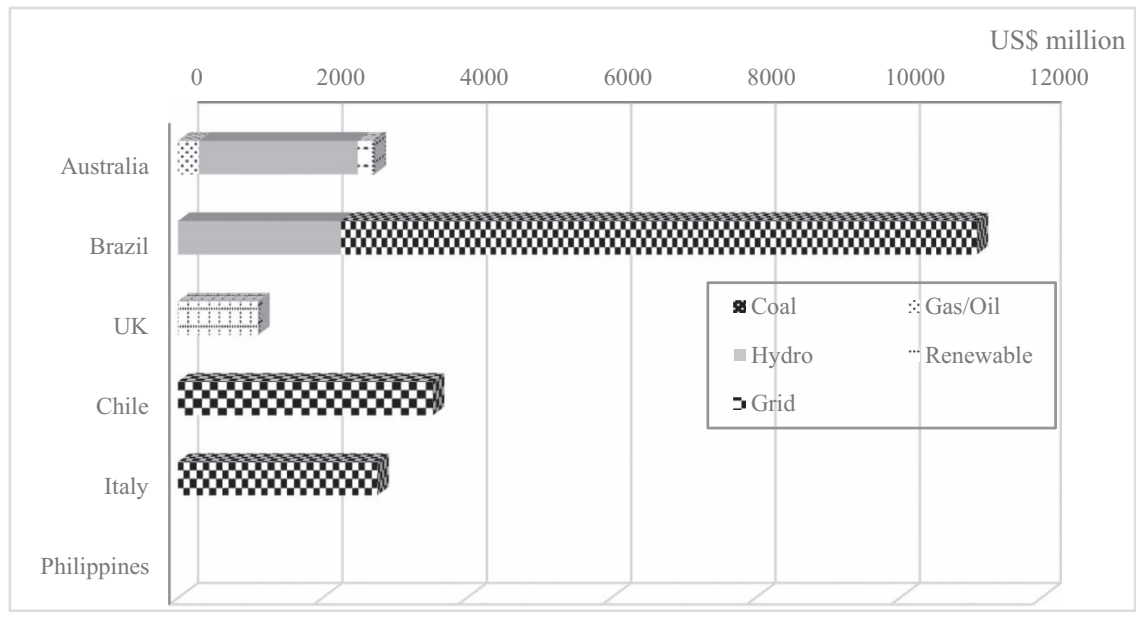

Figure 5.4e Amount of China's brownfield investments by host country and by type of energy in 2014-2019.

Source: Compiled by the author based on sources described in Section 3.2.

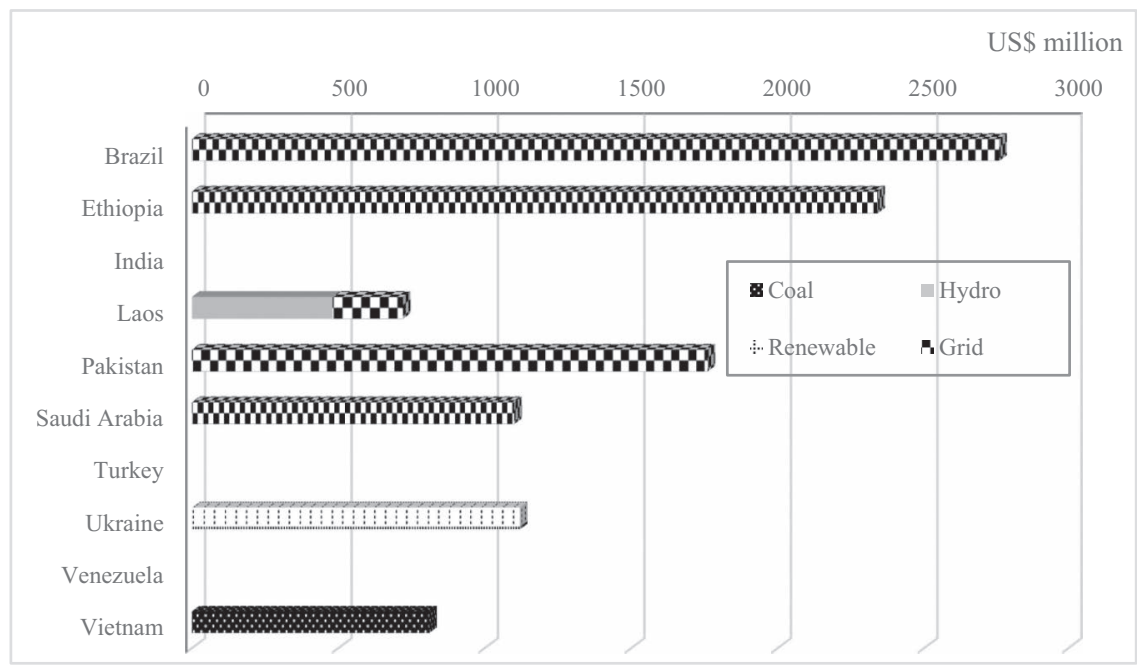

Figure 5.4f Amount of China's contracts by host country and by type of energy in 2014-2019.

Source: Compiled by the author based on sources described in Section 3.2.

\subsection{Summary of the findings}

We summarize the findings as follows. First, the regulated incumbent generators increased investments and contracts in foreign power projects after the government mandate on the upgrade and renovation of coal power 
plants in 2014. Second, their investments and contracts are not comparably larger than those of project developers and incumbent power manufacturers, as well as their newly installed capacity in China. Third, the regulated incumbent generators have shifted from contractors to greenfield investors and concentrated investments in a limited number of countries with investment framework agreements. Finally, grid companies increase geographical diversification in brownfield investment and contacts for grids and renewable energy.

\section{Discussion}

Why have the regulated incumbent generators invested and won contracts smaller than those of the project developers and the incumbent power manufacturers? What generates heterogeneity in a geographical diversification strategy between the regulated incumbent power generators and grid companies and within the regulated incumbent power generators? This section discusses these two questions derived from the results.

\subsection{Capabilities for managing country and credit risk}

There is a distinguished difference in the capabilities for managing a country and credit risk between the regulated incumbent grid companies and power generators. The regulated incumbent grid companies are capable of purchasing a portion of shares and assets of a state-owned utility in host countries and connecting transmission lines to reduce business risk to power generators. They capitalized on the European debt crisis, which started in 2009 , and subsequent privatization of state-owned utilities to purchase them indirectly from their parent companies and foreign stockholders, as well as directly from the utility.

Brazil provides a typical example of how the regulated incumbent grid companies have reduced risks and induced Chinese FDI in power development projects. State Grid acquired seven Brazilian transmission companies from Brazilian Plena Transmissoras (Global Times, 2010), electricity transmission assets in Brazil from Spanish builder Actividades de Construcción y Servicios SA (ACS) (Zhu and Chen, 2012), and a distribution company called Celg Distribuicao SA from state-owned utility Eletrobras (Dezem, 2015). Subsequently, the grid company acquired shares of transmission companies and CPFL Energias, the largest power distributor in Brazil. China Three Gorge Group, one of the unregulated incumbent power generators, also started to acquire a stake in Portuguese utility Energias de Portugal, SA (EDP), establishing a partnership with EDP to obtain half the stakes of the hydropower and wind power projects from its subsidiary EDP Brazil (Macauhub, 2014).

These acquisitions have enhanced Chinese power companies' control over utilities, reducing credit risks for Chinese IPPs. State Grid's investments in transmission lines also reduce curtailment risks of wind and solar 
power producers. The changes in ownership from European to Chinese companies did not raise fear and protests against foreign ownership, as occurred in Australia (Barrett and Fernandez, 2016) and Europe (De Clercq et al., 2014). Subsequently, State Grid's investments triggered a rush of brownfield investments in the assets of hydro, wind, and solar power, including Ilha Solteira and Jupia hydropower, one of the world's largest hydropower plants.

Learning from the Brazil case, Chinese project developers took over the EPC contract on the transmission line in Kenya from Spanish engineering and construction group Isolux Corsan when the company went bankrupt (Oirere, 2018), securing connectivity of their invested hydropower project.

By contrast, the regulated incumbent generators are not capable of doing the same as the grid companies. They have experienced country risk, suspension of projects, and financial loss, despite their national-level partnership agreements. The Cooperation Framework Agreement on Development of Hydroelectric Resources could not prevent the Thein Sein government of Myanmar from suspending the Chibwe Nge, Myitsone, and Chibwe hydropower projects, which were awarded to SPIC in 2008-2011 because of turmoil, local protests, and armed conflicts (SPIC, n.a). The CPEC agreement does not help Pakistan's government avoid abandoning the proposed Datang coal power project that was assumed to use imported coal to supply electricity at an affordable price because of the violation of the ban on imported fuels (Bhutta, 2020). Pakistan's government leaked to the media Huaneng's alleged overcharging by approximately US $\$ 3$ billion by using inflated set-up costs and interest payments in a coal power project (Findlay et al., 2020).

These failures partly explain why the regulated incumbent generators consider geographical diversification as a minor option. Only those who have developers with sufficient capability as subsidiaries or organize strong ties with developers outside of their groups have employed it when they find profitable projects in host countries with stable a business environment. Otherwise, they devote themselves to a domestic response strategy, including lobbying for resuming the new installation of coal power in China (Chen and Ge, 2020). Despite the Chinese government's 27 financial assistance deals with Bangladesh that were agreed upon at the time of Xi Jinping's stopover in 2016 (Rogers, 2016), only Huadian has invested in power projects among the regulated incumbents. The project developers make greenfield investments and win contracts for most of the coal power projects in Bangladesh (Figure 5.5a).

\subsection{Capabilities for developing and managing greenfield investment projects}

The regulated incumbent power generators have heterogeneous capabilities for supplying EPC services and organizing power development projects. 


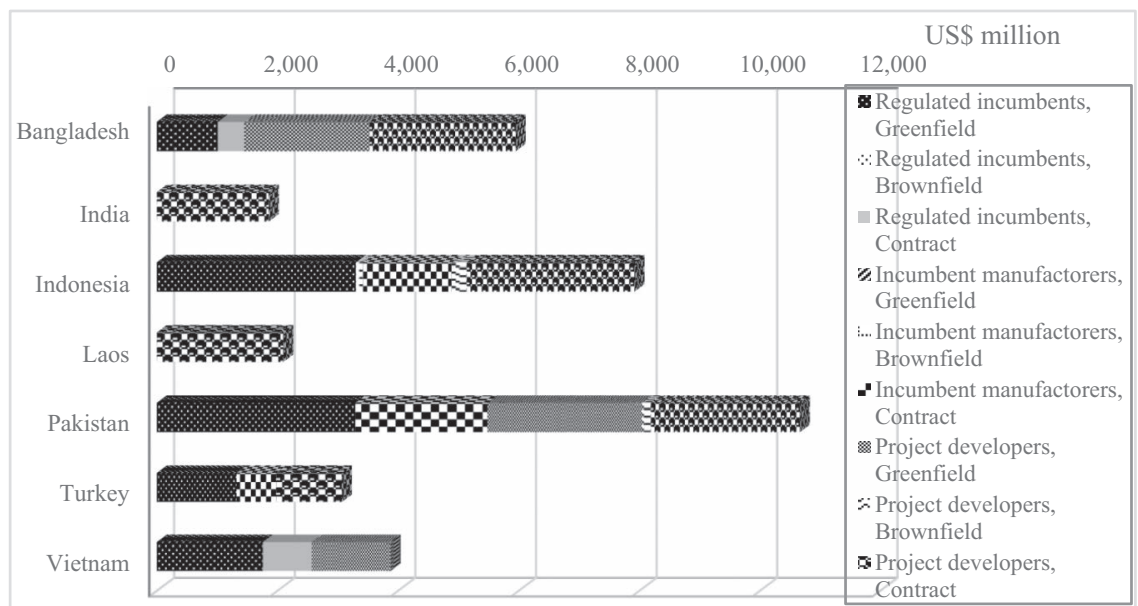

Figure 5.5a Amount of China's investments and contracts in coal power projects by type of Chinese companies in selected host country in 2014-2019.

Source: Compiled by the author based on sources described in Section 3.2.

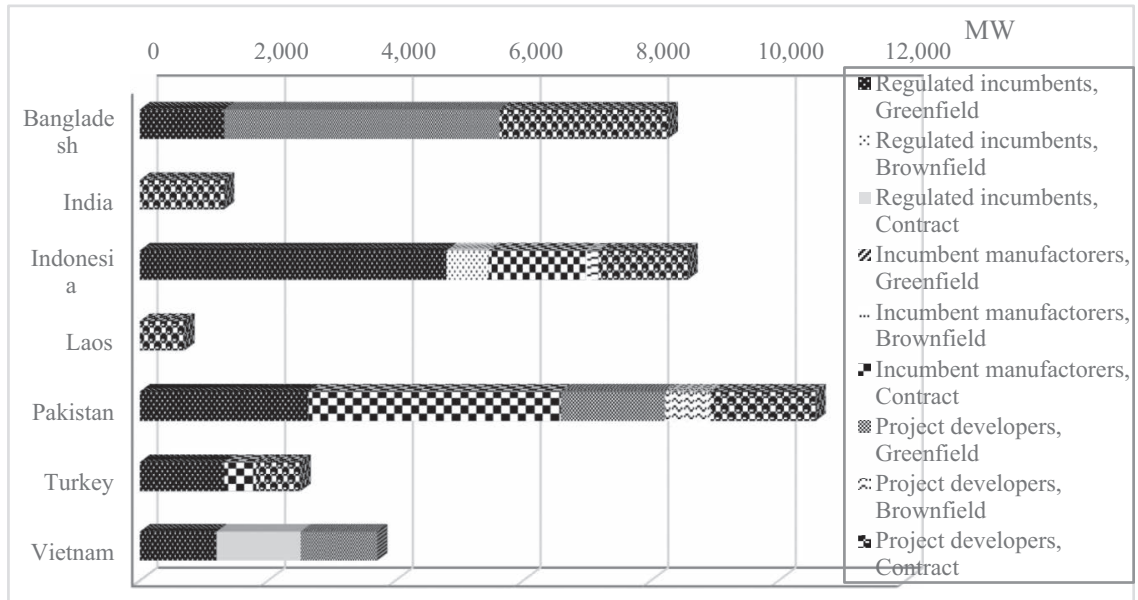

Figure 5.5b Installed capacity by China's investments and contracts in coal power projects by type of Chinese companies in selected host country in 2014-2019.

Source: Compiled by the author based on sources described in Section 3.2.

Host countries that retain vertical integration in their electricity supply system tend to allow participation of foreign companies under EPC contracts and assume that incumbent state electricity companies operate and manage newly developed or renovated generation, grids, transmission, and 
distribution capacity. Only the host countries awarding O\&M contracts or adopting PPP such as a BOT scheme allows foreign power companies to own power generation assets and operate them as IPPs. In host countries that accept bids when selecting developers, to be qualified to join the process, foreign IPPs are required to have sufficient capabilities to develop projects, organize consortiums, and arrange financial schemes.

Thus, the regulated incumbent power companies who have subsidiaries in engineering and/or manufacturing, and take advantage of their close relation with state policy banks (Kong and Gallagher, 2017), have invested in a larger number of foreign power projects. State Grid and Huadian have engineering subsidiaries, China Electric Power Equipment and Technology and Huadian Engineering, capable of providing both EPC and O\&M services and organizing consortiums for bidding. SPIC and Huaneng mobilize their subsidiary power generators, Shanghai electric power, Shandong energy, Shenzhen Power, and Lancang River Hydropower, to increase greenfield investments (Table 5.1); however, they are neither capable nor sufficiently innovative to create new schemes to enhance their competitive edge over the project developers. On the basis of the standardized procedures for the EPC contract established by the Chinese government, the project developers have created new business models such as export credit EPC (FEPC), "Planning + FEPC," mixed-ownership investment, and large-scale mixed loan (China Daily, 2019).

\subsection{Carbon haven effect}

The minor role of geographical diversification in the regulated incumbent generators does not imply that the Chinese electricity sector has not caused the relocation of carbon-intensive plants or the carbon leakage effect in an individual host country and at the plant level.

As analyzed in Section 4.1, regulated incumbents are only one category of Chinese companies who participate in foreign coal power projects. Although they have played a major role in power projects in Indonesia (Figure 5.5a), they account for $20 \%$ and $24 \%$ in the amount of the transaction for Chinese foreign power projects in 2005-2013 and 2014-2019, respectively. The project developers account for the majority, followed by the incumbent power manufacturers. Chinese companies as a whole will increase coal power capacity by more than $8 \mathrm{GW}$ by 2030 in Bangladesh, Pakistan, and Indonesia, mostly due to greenfield investments and contracts by the incumbent manufacturers and the project developers (Figure 5.5b). Because 3-5 GW of newly installed capacity is large enough for countries either with limited installed capacity or in a power crisis to reconfigure the electricity supply system toward a coal-centered system (Mori, 2020), the parallel investments and contracts in new coal power capacity by the three categories of Chinese power companies can play a decisive role in moving and locking host countries' electricity systems into a coal-centered system. 
In this transition, pollution and carbon-intensive plants are relocated across borders. A report demonstrated that the $2 \times 300 \mathrm{MW}$ subcritical coal power plants at the Hunan Chuangyuan power station, forcibly closed in China for violating pollution standards (Global Energy Monitor, Center for Media and Democracy, 2020b), were transferred to Cambodia for use in the second phase of the Sihanoukville Cambodia International Investment Development Group (CIIDG) power projects (MOFCOM, 2020; Polaris Thermal Power Network News, 2018).

Given that State Grid played a substantial role in overcoming the conflict of interest between coal power and wind and solar power in China (Mori, 2018, 2020), grid governance and investment choices can affect carbon leakage and displacement of $\mathrm{CO}_{2}$ emission through Chinese investments and contracts in power projects. If the system actually increases flexibility and network reliability, wind and solar power become profitable businesses. A grid company will probably invest in transmission and wind and solar installed capacity in an integrated manner to maximize profit opportunities (Spring, 2018). By contrast, the grid company may attract coal power investments if it continues to offer an attractive business environment to coal power in a host country with weak grid governance, as in the Philippines after China's State Grid's partial takeover of the National Grid Corporation (Saculsan and Mori, 2020). Which direction to transit depends critically on the good governance of host country; a transparent audit that grids and utilities choose; and developing a secure, flexible, and least-cost system after Chinese companies' takeover (Ahmed, 2020; De Clercq et al., 2014).

\section{Conclusions}

China has increased investments and finance for foreign coal power projects after the government implemented more stringent regulations on air pollution and $\mathrm{CO}_{2}$ emissions. The going global strategy and the BRI create opportunities for the power industry to participate in foreign power projects as investors in greenfield projects, the merger and acquisition of shares and assets, and EPC contractors. These investments and contracts can cause carbon relocation. Recent research has estimated the scale and possible adverse impacts on the environment and the climate crisis; however, most of them have framed the environmental impact in the context of the globalization of Chinese companies and the BRI rather than a response to the stringent environmental regulation.

Against this backdrop, this chapter investigates if power companies employ foreign investments and contracts in power projects as a geographical diversification to the stringent regulations and generate carbon relocation.

Our empirical analysis shows that power project developers and to a less extent coal power plant manufacturers have proactively increased contracts and investments in foreign coal power projects. Although power project developers and coal power plant manufacturers are not regulated, they 
perceive the shrinking Chinese market and seek profit opportunities in foreign countries. The regulated grid companies take advantage of the crises, privatization, and bankruptcies to purchase shares and assets of utilities and national grids, gradually increasing their influence on the direction of power development.

By contrast, the regulated power generators have used foreign power projects as a minor option to circumvent the severe air pollution control regulations at best. The regulated power generators are less capable and innovative enough to compete in international bidding, compared with the project developers and incumbent manufacturers. Although some of them are enhancing the capabilities of developing and managing projects, to shift from contractors to investors and developers, only a few countries accept IPPs, limiting their investment opportunities. Coupled with their initial failure in foreign projects, this results in greenfield investments in a limited number of host countries.

These results suggest that Chinese climate-energy-air pollution control policies, coupled with the going global strategy and the BRI, cause the partial relocation of carbon-intensive processes in the electricity sector. The electricity supply system is more likely to be reconfigured toward a coal-centered system in host countries with weak grid governance and massive investments and contracts from China under investment framework agreements.

A further challenge is to explore how to reconcile environmental and climatic consequences of these Chinese investments and contracts in coal power with the Nationally Determined Contributions to the Paris Agreement in these host countries. We discuss this challenge in the conclusion chapter.

\section{Acknowledgments}

The author thanks Dr. Gregory Trencher for his comments at the annual conference of the Society for Environmental Economics and Policy Studies (SEEPS) on 26 September 2020. This chapter is financially supported by Murata Foundation H31-GH-31 as well.

\section{Notes}

1 An acquisition of assets under construction enables investors to save transaction costs in terms of development of potential projects, administrative procedure, land acquisition, environmental and social impact assessments, and consensus building.

2 National Development and Reform Commission, Ministry of Environmental Protection and National Energy Administration (2014), Notification on the Action Plan for Upgrading and Transformation of the Energy Conservation and Emission Reduction of Coal-fired Power (2014-2020) (Editorial Board of China Electric Power Yearbook, 2016: 669-672). 
3 MOFCOM, Foreign investment projects, http://projct.mofcom.gov.cn [accessed 1 September 2020].

4 Project developers often provide equity finance as project owners to organize financial arrangement and may assign themselves as EPC contractors.

5 Author's calculation based on Editorial Board of China Electric Power Yearbook (2015) and China Electric Council (2020).

\section{References}

Ahmed, S.J., 2020. IEEFA update: China's state grid group triggers oversight controversy in the Philippines, (18 February 2020), https://ieefa.org/ieefa-updatechinas-state-grid-group-triggers-oversight-controversy-in-the-philippines/, [accessed 17 August 2020].

Al-mulali, U., C.F. Tang, 2013. Investigating the validity of pollution haven hypothesis in the gulf cooperation council (GCC) countries. Energy Pol. 60, 813-819. https://doi.org/10.1016/j.enpol.2013.05.055.

Ali, M., 2009. Indonesia power firm signs loan agreements for over \$1 bln, Reuters, 14 October 2009, https://www.reuters.com/article/indonesia-power-loan/indonesiapower-firm-signs-loan-agreements-for-over-1-bln-idUSJAK 54822220091014/, [accessed 14 April 2019].

American Enterprise Institute and the Heritage Foundation, 2020. The China Global Investment Tracker, https://www.aei.org/china-global-investment-tracker/, [accessed 20 July 2020].

Arce, G., L.A. López, D. Guan, 2016. Carbon emissions embodied in international trade: The post-China era, Appl Energy 184: 1063-1072, http://dx.doi.org/10.1016/ j.apenergy.2016.05.084.

Asghari, M., 2013. Does FDI promote MENA region's environment quality? Pollution halo or pollution haven hypothesis. Int. J. 1(6), 92-100, http://dx.doi. org/10.12983/ijsres-2013-p092-100.

Baek, J., 2016. A new look at the FDI-income-energy-environment nexus: Dynamic panel data analysis of ASEAN. Energy Pol. 91, 22-27, https://doi.org/10.1016/j. enpol.2015.12.045.

Barrett, J., C. Fernandez, 2016. Australian treasurer formally rejects Chinese bids for state-owned Ausgrid, Reuters, (19 August 2016), https://www.reuters.com/ article/australia-privatisation-ausgrid/australian-treasurer-formally-rejectschinese-bids-for-state-owned-ausgrid-idUSS9N1AR003/, [accessed 23 August 2020].

Beardsworth, J.J. Jr., J.A. Schmidt, 2014. Resource financed infrastructure: Origins and issues, In: Halland, H., J. Beardsworth, B. Land, and J. Schmidt, Resource Financed Infrastructure, A Discussion on a New Form of Infrastructure Financing, The World Bank, Washington DC, 11-68, http://dx.doi.org/10.1596/978-1-4648-0239-3.

Bhutta, Z. 2020, PTI govt abandons K-Electric's coal project, Tribune (25 June 2020), https://tribune.com.pk/story/2249796/pti-govt-abandons-k-electrics-coalprojec/, [accessed 3 September 2020].

Blanchard, J.M.F. 2017. Probing China's Twenty-First-Century Maritime Silk Road Initiative (MSRI): An examination of MSRI narratives, Geopolitics 22(2): 246-268, https://doi.org/10.1080/14650045.2016.1267147.

Boulle, M., 2019. The hazy rise of coal in Kenya: The actors, interests, and discursive contradictions shaping Kenya's electricity future, Energy Res. Soc. Sci. 56: 101205, https://doi.org/10.1016/j.erss.2019.05.015. 
Brautigam, D., 2009. The Dragon's Gift: The Real Story of China in Africa, Oxford University Press: Oxford.

Brautigam, D., K.P. Gallagher, 2014. Bartering globalization: China's commoditybacked finance in Africa and Latin America, Global Policy 5(3), 346-357, https:// doi.org/10.1111/1758-5899.12138.

Brautigam, D., J. Hwang, J. Link, K. Acker, 2019. Chinese Loans to Africa Database, China Africa Research Initiative, Johns Hopkins University School of Advanced International Studies, Washington, DC, http://www.sais-cari.org/s/LoanData_ 17July2020.xlsx/, [accessed 23 July 2020].

Candau, F., E. Dienesch, 2017. Pollution haven and corruption paradise, J. Environ. Econ. Manag. 85, 171-192, https://doi.org/10.1016/j.jeem.2017.05.005.

Cardoso, D., 2013. China-Brazil: A strategic partnership in an evolving world order, East Asia 30(1), 35-51, https://doi.org/10.1007/s12140-012-9186-z.

Castle, J.W., A. Manuwoto, 2011. Indonesian Business: The Year in Review 2010, Equinox Publishing (Asia), Jakarta.

Chen, X., Y. Ge, 2020. China fires up coal power plant construction: Surge in first-quarter approvals possibly related to COVID-19 outbreak, (5 May, 2020), Nikkei Asian Review, https://asia.nikkei.com/Spotlight/Caixin/China-fires-upcoal-power-plant-construction/, [accessed 26 August 2020].

Cherniwchan, J., B.R. Copeland, M.S. Taylor, 2017. Trade and the environment: New methods, measurements, and results, Annu. Rev. Econ. 9, 59-85, https://doi. org/10.1146/annurev-economics-063016-103756.

China Daily, 2019. POWERCHINA forges ahead with innovative international business models, (18 April 2019), http://www.chinadaily.com.cn/m/ powerchina/2019-04/18/content_37459891.htm/, [accessed 30 August 2020].

China Electric Council, 2020. 2019 China Electric Industry Economic Performance Analysis, (in Chinese), http://lwzb.stats.gov.cn/pub/lwzb/gzdt/202005/ W020200528770641853077.pdf/, [accessed 7 September 2020].

Christmann, P., 2004. Multinational companies and the natural environment: Determinants of global environmental policy standardization, Acad. Manag. J. 47, 747-760.

De Clercq, G., C. Zhu, S. Jewkes, 2014. China State Grid quietly builds Mediterranean power network, (10 August 2014), https://www.reuters.com/ article/utilities-mediterranean-china/china-state-grid-quietly-buildsmediterranean-power-network-idUSL6N0QB5NF20140810/, [accessed 23 August 2020].

Dean, J.M., M.E. Lovely, H. Wang, 2009. Are foreign investors attracted to weak environmental regulations? Evaluating the evidence from China, J. Dev. Econ. 90, 1-13.

Dezem, V. 2015. Brazil's Eletrobras approves sales of energy distributor Celg-D, Latin America \& Caribbean Energy Program, https://www.jsg.utexas.edu/ lacp/2016/01/brazils-eletrobras-approves-sale-of-energy-distributor-celg-d/, [accessed 24 August 2020].

Dreher, A., A. Fuchs, B. Parks, A.M. Strange, M.J. Tierney. Aid, China, and growth: Evidence from a New Global Development Finance Dataset, forthcoming in American Economic Journal: Economic Policy, https://www.aeaweb.org/ articles?id=10.1257/pol.20180631\&\&from=f/, [accessed on 4 August 2020].

Editorial Board of China Electric Power Yearbook, 2015. 2014 China Electric Power Yearbook, China Electric Power Press, Beijing (in Chinese). 
Editorial Board of China Electric Power Yearbook, 2016. 2015 China Electric Power Yearbook, China Electric Power Press, Beijing (in Chinese).

Endcoal, 2020. Global coal public finance tracker, https://endcoal.org/financetracker/, [accessed on 4 August 2020].

Eskeland, G.S., A.E. Harrison, 2003. Moving to greener pastures? Multinationals and the pollution haven hypothesis, J Dev Econ 70: 1-23, https://doi.org/10.1016/ S0304-3878(02)00084-6.

Feng, T.T., X.L. Gong, Y.H. Guo, Y.S. Yang, B.B. Pan, S.P. Li, J. Dong, 2020. Electricity cooperation strategy between China and ASEAN countries under 'The Belt and road,' Energy Strategy Rev 30, 100512.

Findlay, S., F. Bokhari, S. Yu, 2020. Islamabad wants to renegotiate repayment after claiming costs of power plants were inflated, Financial Times (26 June 2020), https://www.ft.com/content/4af8101b-599c-407d-8850-3fd27cd9b31c/, [accessed on 1 July 2020].

Gallagher, K.P., 2018a. China’s Global Energy Finance, Boston University Global Development Policy Center, Boston, https://www.bu.edu/cgef/\#/all/Country/ Global/, [accessed 4 August 2020].

Gallagher, K.P., 2018b. China's Global energy finance: Poised to lead, Energy Res. Soc. Sci. 35, 15-16, https://doi.org/10.1016/j.erss.2018.01.001.

Gallagher, K.P., R. Kamal, J. Jin, Y. Chen, X. Ma, 2018. Energizing development finance? The benefits and risks of China's development finance in the global energy sector, Energy Policy 122, 313-321, https://doi.org/10.1016/j.enpol. 2018.06.009.

Gilley, B., 2012. Authoritarian environmentalism and China's response to climate change, Environmental Politics 21(2): 287-307, http://dx.doi.org/10.1080/09644016 .2012.651904.

Global Energy Monitor, Center for Media and Democracy, 2020a. International Chinese coal projects, https://www.gem.wiki/International_Chinese_coal_ projects/, [accessed on 11 August 2020].

Global Energy Monitor, Center for Media and Democracy, 2020b. Sihanoukville CIIDG power station 2, https://www.gem.wiki/Sihanoukville_CIIDG_power_ station_2/, [accessed on 5 August 2020].

Global Times, 2010. State Grid to buy Brazilian power giants, (27 August 2010), http://www.china.org.cn/business/2010-08/27/content_20805031.htm/, [accessed 24 August 2020].

Hervé-Mignucci, M., X. Wang, 2015. Slowing the growth of coal power outside China: The role of Chinese Finance, A CPI Report, Climate Policy Initiative, https:/climatepolicyinitiative.org/wp-content/uploads/2015/11/Slowing-theGrowth-of-Coal-Power-Outside-China.pdf/, [accessed 20 April 2020].

International Energy Agency (IEA), 2013. Redrawing the Energy Climate Map, World Energy Outlook Special Report, https://webstore.iea.org/download/ summary/480?fileName=English-WEO-Climate-2013-ES.pdf/, [accessed $18 \mathrm{Au}-$ gust 2020].

Kivyiro, P., H. Arminen, 2014. Carbon dioxide emissions, energy consumption, economic growth, and foreign direct investment: Causality analysis for Sub-Saharan Africa, Energy 74:595-606, https://doi.org/10.1016/j.energy.2014.07.025.

Kong, B., K.P. Gallagher, 2017. Globalizing Chinese energy finance: The role of policy banks, J. Contemp. China 26:108, 834-851, http://dx.doi.org/10.1080/10670 564.2017.1337307. 


\section{Akihisa Mori}

Kungl, G., 2015. Stewards or sticklers for change? Incumbent energy providers and the politics of the German energy transition, Energy Res. Soc. Sci. 8, 13-23, https://doi.org/10.1016/j.erss.2015.04.009.

LGS Online, 2009. PLN may possibly miss target for second 'fast-track' scheme, (26 February 2009), http://www.lgsonline.com/pages/g/lgsimp997/node/lgs4a1d77eb 99e7a/, [accessed 14 April 2019].

Li, Z., K.P. Gallagher, D. Mauzerall, 2020. Supplementary information for China's global power, https://docs.google.com/spreadsheets/d/1jPyn4unb 061x0trME4X-BhksiUUJGPSIoLpzLDAelps/edit\#gid=0/, [accessed 23 May 2020].

Lin, J.Y., Y. Wang, 2017. Going Beyond Aid: Development Cooperation for Structural Transformation, World Bank, Washington DC.

Macauhub, 2014. EDP Brazil completes sale to China Three Gorges of stakes in hydroelectric projects, (30 June 2014), https://macauhub.com.mo/2014/06/30/edpbrasil-completes-sale-to-china-three-gorges-of-stakes-in-hydroelectric-projects/, [accessed 22 August 2020].

Markard, J., V.H. Hoffmann, 2016. Analysis of complementarities: Framework and examples from the energy transition, Technol. Forecast. Soc. Change 111, 63-75, https://doi.org/10.1016/j.techfore.2016.06.008.

Millimet, D.L., Roy, J., 2015. Empirical tests of the pollution haven hypothesis when environmental regulation is endogenous. J. Appl. Econ. 31, 652-677, https://doi. org/10.1002/jae.2451.

Ministry of Commerce China (MOFCOM), 2020. The first phase of the 2 x $300 \mathrm{MW}$ coal power plant project in the Sihanoukville Special Economic Zone in Cambodia (procurement and construction) (柬埔寨西哈努克斯敦豪经济特区2台300兆瓦 燃煤电站一期项目(PC)), http://project.fdi.gov.cn/1800000091_1_111773_0_7.htm1/, (in Chinese) [accessed 5 August 2020].

Mori, A. 2018. Sociotechnical and political economy perspectives in the Chinese energy transition, Energy Res Soc Sci 35: 29-36, https://doi.org/10.1016/ j.erss.2017.10.043.

Mori, A. 2020. Foreign actors, faster transitions? Co-evolution of complementarities, perspectives and sociotechnical systems in the case of Indonesia's electricity supply system, Energy Res. Soc. Sci. 69: 101594, https://doi.org/10.1016/ j.erss.2020.101594.

OECD, 2015. Sector understanding on export credits for coal-fired electricity generation projects, TAD/PG(2015)9/FINAL, https://www.oecd.org/officialdocuments/ publicdisplaydocumentpdf/?cote $=\mathrm{TAD} / \mathrm{PG}(2015) 9 / \mathrm{FINAL} \&$ docLanguage $=\mathrm{En} /$, [accessed 19 August 2020].

Oirere, S. 2018. Chinese firms supplant Spanish Group in East Africa power transmission project, Engineering News-Record (13 March 2018), https://www.enr. com/articles/44150-chinese-firms-supplant-spanish-group-in-east-africa-powertransmission-project/, [accessed 24 August 2020].

Panhans, M., L. Lavric, N. Hanley, 2017. The effects of electricity costs on firm re-location decisions: Insights for the pollution havens hypothesis? Environ. Resource Econ. 68, 893-914, https://doi.org/10.1007/s10640-016-0051-1.

Peng, R., C. Liu, L. Zhang, 2017. China's involvement in coal-fired power projects along the belt and road, Global Environmental Institute, http://www.geichina. org/_upload/file/report/China's_Involvement_in_Coal-fired_Power_Projects_ OBOR_EN.pdf/, [accessed 19 August 2020]. 
People's Republic of China and the Republic of Indonesia, 2015. Joint Statement on Strengthening Comprehensive Strategic Partnership between the People's Republic of China and the Republic of Indonesia, 27 March 2015, http://id.chinaembassy.org/eng/zgyyn/zywx/t1249223.htm/, [accessed 14 June 2019].

Penning, E., L. Sleuwaegen, 2000. International relocation: firm and industry determinants, Econ. Lett. 67(2): 179-186, https://doi.org/10.1016/S0165-1765(99)00269-4.

Platts, 2015. Data Base Description and Research Methodology UDI World Electric Power Plants Data Base, McGraw Hill Financial, Washington DC.

Polaris Thermal Power Network News (北极星电力网新闻中心), 2018. Coal power plant project in the Sihanoukville Special Economic Zone in Cambodia started (柬埔寨西哈努克斯敦豪经济特区燃煤电站项目开工), (20 November 2018), http:// news.bjx.com.cn/html/20181120/942881.shtml/, (in Chinese) [accessed 5 August 2020].

Ren, S., B. Yuan, X. Ma, X. Chen, 2014. International trade, FDI (foreign direct investment) and embodied $\mathrm{CO} 2$ emissions: A case study of Chinas industrial sectors, China Econ. Rev. 28: 123-134, https://doi.org/10.1016/j.chieco.2014.01.003.

Rogers, D. 2016. Bangladesh a "rising tiger" thanks to $\$ 40 \mathrm{bn}$ in Chinese deals, Global Construction Review (18 October 2016), https://pt.globalconstructionreview.com/ news/bangladesh-rising-tig7er-than7ks-40bn-chin7ese/\#googtrans(en|pt)/, [accessed 1 September 2020].

Saculsan, P.G., A. Mori, 2020. Why developing countries go through an unsustainable energy transition pathway? The case of the Philippines from a political economic perspective. J. Sust. Res. 2(2): 1-24, https://doi.org/10.20900/jsr20200012.

Sapkota, P., U. Bastola, 2017. Foreign direct investment, income, and environmental pollution in developing countries: Panel data analysis of Latin America, Energy Econ. 64: 206-212, https://doi.org/10.1016/j.eneco.2017.04.001.

Scissors, D., 2020. China's global investment in 2019: Going out goes small, Working Paper, American Enterprise Institute, https://www.aei.org/wp-content/ uploads/2020/01/Chinas-global-investment-in-2019-1.pdf/, [accessed 23 July 2020].

Shearer, C., M. Brown, T. Buckley, 2019. China at a Crossroads: Continued Support for Coal Power Erodes Country's Clean Energy Leadership, Institute for Energy Economics and Financial Analysis, http://ieefa.org/wp-content/uploads/2019/01/ China-at-a-Crossroads_January-2019.pdf, [accessed 22 July 2020].

Solarin, S.A., U. Al-Mulali, I. Musah, I. Ozturk, 2017. Investigating the pollution haven hypothesis in Ghana: An empirical investigation, Energy 124: 706-719, https://doi.org/10.1016/j.energy.2017.02.089.

Spring, J., 2018. China's State Grid to invest $\$ 38$ billion in Brazil power sector, Reuters (31 May 2018), https://www.reuters.com/article/us-brazil-power-state-gridcorp/chinas-state-grid-to-invest-38-billion-in-brazil-power-sector-idUSK CN1IV2SR/, [accessed 17 August 2020].

State Power Investment Corporation (SPIC), n.a, Business Networking, http://eng. spic.com.cn/2016SiteEn/SPICGlobal/BusinessNetworking/, [accessed 3 September 2020].

Tao, Y., H. Liang, M.A. Celia, 2020. Electric power development associated with the Belt and Road Initiative and its carbon emissions implications, Appl Energy 267, 114784, https://doi.org/10.1016/j.apenergy.2020.114784.

Tobey, J., 1990. The effects of domestic environmental policies on patterns of world trade: an empirical test, Kyklos 43(2): 191-209, https://doi.org/10.1111/ j.1467-6435.1990.tb00207.x. 
Turnheim, B., B.K. Sovacool, 2020. Forever stuck in old ways? Pluralising incumbencies in sustainability transitions, Environ. Innov. Soc. Transit. 35, 180-184, https://doi.org/10.1016/j.eist.2019.10.012.

Ueno, T., M. Yanagi, J. Nakano, 2014. Quantifying Chinese public financing for foreign coal power plants, Working Paper GraSPP-DP-E-14-003, Graduate School of Public Policy at University of Tokyo, http://www.pp.u-tokyo.ac.jp/graspp-old/ research/dp/documents/GraSPP-DP-E-14-003.pdf/, [accessed 19 August 2020].

Vidal, J., 2016. Bangladesh coal plant protests continue after demonstrators killed, The Guardian, (6 April 2016), http://www.theguardian.com/environment/2016/ apr/06/bangladesh-coal-plant-protests-continue-after-demonstrators-killed/, [accessed 19 August 2020].

Wang, D.T., W.Y. Chen, 2014. Foreign direct investment, institutional development, and environmental externalities: Evidence from China, J. Environ. Manag. 135, 81-90, http://dx.doi.org/10.1016/j.jenvman.2014.01.013.

Wang Z., S. Chen, C. Cui, Q. Liu, L. Deng, 2019. Industry relocation or emission relocation? Visualizing and decomposing the dislocation between China's economy and carbon emissions, J. Clean. Prod. 208, 1109-1119, https://doi.org/10.1016/ j.jclepro.2018.10.166.

White House, 2015. FACT SHEET: The United States and China Issue Joint Presidential Statement on Climate Change with New Domestic Policy Commitments and a Common Vision for an Ambitious Global Climate Agreement in Paris, https://obamawhitehouse.archives.gov/the-press-office/2015/09/25/fact-sheetunited-states-and-china-issue-joint-presidential-statement/, [accessed 19 August 2020].

Xie, E. 2020. Climate change: Xi Jinping makes bold pledge for China to be carbon neutral by 2060, South China Morning Post (23 September 2020), https://www. scmp.com/news/china/diplomacy/article/3102761/climate-change-xi-jinpingmakes-bold-pledge-china-be-carbon/, [accessed 20 October 2020].

Xiong, M., X. Yang, S. Chen, F. Shi, J. Yuan, 2019. Environmental stress testing for China's overseas coal power investment project, Sustainability 11: 5506, https:// doi.org/10.3390/su11195506.

Yin, R.K., 2014. Case Study Research: Design and Methods, Fifth ed., Sage Publications, Thousand Oaks, CA.

Zhao, X., C. Liu, C. Sun, M. Yang, 2020. Does stringent environmental regulation lead to a carbon haven effect? Evidence from carbon-intensive industries in China, Energy Econ. 86, 104631, https://doi.org/10.1016/j.eneco.2019.104631.

Zheng, D., M. Shi, 2017. Multiple environmental policies and pollution haven hypothesis: Evidence from China's polluting industries. J. Clean. Prod. 141, 295-304. https://doi.org/10.1016/j.jclepro.2016.09.091

Zhu, C., M. Chen, 2012. UPDATE 2-China's State Grid to buy Brazil assets from Spain's ACS, Reuters, (29 May 2012), https://www.reuters.com/article/stategrid-brazil/update-2-chinas-state-grid-to-buy-brazil-assets-from-spains-acsidUSL4E8GT3QM20120529/, [accessed 24 August 2020].

Zugravu-Soilita, N., 2017. How does foreign direct investment affect pollution? Toward a better understanding of the direct and conditional effects, Environ. Resour. Econ. 66(2), 293-338, https://doi.org/10.1007/s10640-015-9950-9. 